Vol. 7(1998): 219-250.

\title{
Supply of nutrients and productive responses in dairy cows given diets based on restrictively fermented silage
}

\author{
Pekka Huhtanen \\ Agricultural Research Centre of Finland, Animal Production Research, FIN-31600 Jokioinen, \\ Finland, e-mail: pekka.huhtanen@mtt.fi
}

\begin{abstract}
The objective of this paper is to review research which has evaluated the feeding of dairy cows with diets containing large proportions of grass silage. In Finland, milk production systems evolved are based on the use of restrictively fermented silages. Higher potential yields, smaller production risks than with cereal grains, short grazing period and high digestibility of grasses grown in northern latitudes have facilitated this development. Factors affecting nutrient supply from these diets are discussed. Digestibility is determined mainly by the stage of maturity at harvesting and it is not markedly affected by the level of energy and protein supplementation. Intake of grass silage is influenced both by digestibility and fermentation characteristics. Efficiency of microbial synthesis is high in animals given diets based on restrictively fermented silage but rumen fermentation pattern is characterised by low molar proportions of propionate. Production responses to additional concentrate are relatively small, especially when the amount of concentrate exceeds $10 \mathrm{~kg} \mathrm{day}^{-1}$. High substitution of silage dry matter (DM), negative associative effects on digestion and partitioning of energy towards body tissues account for small production responses. Protein supplementation has consistently increased milk protein yield but responses do not appear to be related to the level of milk production, silage crude protein content, amount of concentrate or stage of lactation. The new protein evaluation system provides an accurate prediction of protein yield with the typical Finnish dairy cow diets. The high slopes (ca. 0.5 ) between protein supply and milk protein yield within experiments suggest that protein supply is suboptimal and protein supplements are used with a high efficiency.
\end{abstract}

Key words: energy, milk production, nutrient supply, protein, response to nutrients, silage

\section{Introduction}

Domesticated ruminants are well adapted to different environmental conditions and diets. Milk production systems adopted in different climat- ic zones employ contrasting input levels. High concentrate diets are used in many Western countries, whereas dairy cow rations fed in New Zealand are mainly comprised $(90 \%)$ of grazed pasture. In Finland grazed pasture cannot contribute more than $25-30 \%$ of annual energy intake 


\section{AGRICULTURAL AND FOOD SCIENCE IN FINLAND}

Seminar in honour of the 100th anniversary of MTT

owing to a short (100-120 days) grazing period. Long indoor feeding period and a large yeararound demand of milk products have increased the importance of conserved forages in dairy cow diets. High concentrate costs and a shortage of domestic protein supplements have favoured the development of forage-based feeding systems. Invention of silage additives by professor A.I. Virtanen established a firm background for silage-based feeding systems. Although he was granted a Nobel prize in 1945 for these inventions, silage production did not increase in Finland until the 1960s when flail-type forage harvesters became widely available. This generated an extensive research programme into grassland production, ensiling, and feeding and supplementation of grass silage. This research programme led to the development of a silage-based 'Green Line' feeding system, which is now widely adopted in Finland.

There are several reasons why grass silagebased feeding system has been adopted in Finland. Higher yield potential with smaller production risks of grasses compared with cereal grains has favoured grass production. In field experiments dry matter (DM) yields of timothy (Phleum pratense) and meadow fescue (Festuca pratensis) in North Ostrobothnia $\left(64^{\circ} 40^{\prime} \mathrm{N}\right)$ and North Savo $\left(63^{\circ} 10^{\prime} \mathrm{N}\right)$ are generally from 9000 to $10000 \mathrm{~kg} / \mathrm{ha}$ for 1-3-year old swards (Nissinen and Hakkola 1995, Rinne, K. et al. unpublished). At the same research stations DM yields of barley are ca. $5000 \mathrm{~kg} / \mathrm{ha}$. Despite lower contents of metabolisable energy (ME) and higher storage losses of grass silage than with grain, feed energy yield per hectare is considerably higher from grass than from grain production, especially in the middle and northern parts of Finland. Higher crude protein content of grass was also considered as an advantage when protein supplements were not widely available.

Winter feeding systems based on grass silage provide several advantages compared with haybased systems. Silage making is much less dependent on weather conditions than hay making and harvesting losses are generally smaller for silage than hay (Pitt 1991). When conserved as silage, the swards can be harvested at an earlier stage of growth and therefore the nutritional value of silage is higher.

Owing to the long winter feeding period and high building costs milk production must be intensive to be profitable. However, because of high cereal grain and other concentrate prices, intensive milk production in Finland has been based on production and feeding of high-quality forages rather than increasing the proportion of concentrates in the diet. This strategy has been successful since annual milk yield in controlled herds increased from $5859 \mathrm{~kg}$ in 1987 to 7186 $\mathrm{kg}$ in 1997 without marked increase in the proportion of concentrates in the diet [ca. $350 \mathrm{~g} \mathrm{(kg}$ $\left.\mathrm{DM}^{-1}\right)$ ]. In addition to the high nutrient content of silage, a good hygienic quality has even allowed production of Emmenthal cheese in Finnish dairies from milk produced by silage-fed cows. Milk quota, adopted in Finland in 1985, should encourage farmers to reduce unit costs of production and concentrate inputs. In contrast, subsidy policies of the European Union (EU) have considerably reduced the relative price of concentrates in Finland. Biased price ratios of concentrates to forages in relation to their natural production costs could jeopardise the sustainable milk production system in Finland. The impacts of concentrate-based systems on animal welfare and environmental issues would be deleterious. Furthermore, the image of milk currently held by consumers as being natural and healthy would also be threatened, if high concentrate diets are fed to dairy cows.

Research interests during the last two decades have focused on optimisation of forage conservation, determination of nutrient supply, supplementation of grass silage-based diets, optimisation of diet composition to improve nutrient utilisation and milk composition and to reduce environmental pollution. Factors affecting nutritive value and supplementation of grass silage have been discussed in several reviews (Thomas and Thomas 1985, Thomas and Rae 1988, Lampila et al. 1988, Chamberlain et al. 1989, Harrison et al. 1994, van Vuuren et al. 1995). This paper will focus more specifically on nu- 


\section{AGRICULTURAL AND FOOD SCIENCE IN FINLAND}

Vol. 7 (1998): 219-250.

trient supply and response to nutrients with diets based on restrictively fermented silages widely used in Finland.

\section{Nutrient supply from grass silage-based diets}

The amount of nutrients absorbed from the digestive tract depends on the content of digestible nutrients in the feed and DM intake. Most of the variation in net energy content of a feed is associated with digestibility, while methane and urinary losses and differences in the utilisation of $\mathrm{ME}$ account for relatively little variation.

\section{Digestibility}

\section{Fermentation}

Chemical composition and digestibility of grass silage are affected by maturity at harvest more than by other management factors such as particle size, DM at harvest and harvesting system. The effect of ensiling on digestibility is often small provided that silage is not badly fermented and effluent production is minimised. Wellpreserved silages can be classified as high-lactate or restrictively fermented silages. The former can be produced by natural fermentation without the use of additives or as a result of using bacterial inoculants, enzymes or low rates of formic or other acid acids. Restrictively fermented silages are generally produced by high application rates of formic acid (FA) during ensiling. Digestibility of high-lactate silages has been reported to be similar to that of restrictively fermented formic FA-treated silages (Jaakkola 1992, Harrison et al. 1994). Huhtanen et al. (1997a) and Heikkilä et al. (1998a) reported that organic matter (OM) digestibility in dairy cows fed inoculant-treated silage was higher than that treated with FA. A lower digestibility of neutral detergent fibre (NDF) of FA-treated silage ap- peared to account for this difference. Enzymes have been used as silage additives in an attempt to supply more fermentable substrates for lactic acid bacteria. Earlier it was also assumed that enzymes would improve silage digestibility, thereby permitting later harvesting and higher DM yields without reduced digestibility. However, studies reviewed by Jaakkola (1992) showed that cell wall degrading enzymes did not improve OM digestibility and in fact decreased cell wall digestibility. As a result of preferential in silo degradation of the highly digestible cell wall material by enzymes, less digestible residue is left for ruminal digestion. Harrison et al. (1994) reported that enzyme treatment improved silage DM digestibility in one-third of the comparisons.

\section{Maturity}

The decline in digestibility of grass with proceeding stage of growth is faster at northern latitudes (Deinum et al. 1981). For example, in the UK the decline in OM digestibility is typically $3 \mathrm{~g} \mathrm{~kg}^{-1}$ per day whereas in Finland it is approximately $5 \mathrm{~g} \mathrm{~kg}^{-1}$ per day. The faster decline in digestibility at northern latitudes is related to a more rapid stem development and to smaller proportion of leaf DM (Deinum et al. 1981). However, at the same morphological stage the digestibility of the whole grass crop is higher at northern latitudes. Lower temperature, long day and high solar radiation would promote DM accumulation, without much effect on ageing and digestibility (Van Soest et al. 1978). At 50\% and $70 \%$ content of leaf sheaths and stems in vitro digestibility of timothy was 80 and $170 \mathrm{~g} \mathrm{~kg}^{-1}$ higher in Tromsö $\left(69^{\circ} \mathrm{N}\right)$ than in Wageningen $\left(52^{\circ} \mathrm{N}\right)$ (Deinum et al. 1981).

Lignification in the cell wall fraction increases with plant maturity, which reduces its digestibility and, consequently, energy value of grasses. The lower temperature reduces lignification, and therefore the digestibility of plant material is maintained at a high level (700-750 $\left.\mathrm{g} \mathrm{kg}^{-1}\right)$ even

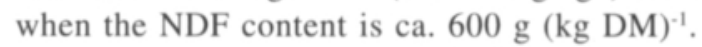
The mean decline of digestibility in four studies conducted at $60-61^{\circ} \mathrm{N}$ with first-cut silages 


\section{AGRICULTURAL AND FOOD SCIENCE IN FINLAND}

\section{Seminar in honour of the 100th anniversary of MTT}

was $5.4 \mathrm{~g} \mathrm{~kg}^{-1}$ per day (Fig. 1). The rate of decline is not always linear being generally slower at the beginning of the growing season when the rate of DM accumulation is slow. The fastest daily declines in $\mathrm{OM}$ digestibility of 8 to $10 \mathrm{~g}$ $\mathrm{kg}^{-1}$ per day often occurred during the recommended harvesting time. OM digestibility (OMD) was positively correlated with silage crude protein (CP) content and negatively with NDF in four studies using 18 silages:

OMD $\left(\mathrm{g} \mathrm{kg}^{-1}\right)=532+1.393 \times \mathrm{CP}\left(\mathrm{g} \mathrm{kg}^{-1}\right)$

$\left(\mathrm{R}^{2}=0.696\right.$; SE est. 32.8)

OMD $\left(\mathrm{g} \mathrm{kg}^{-1}\right)=1115-0.669 \times \mathrm{NDF}\left(\mathrm{g} \mathrm{kg}^{-1}\right)$ $\left(\mathrm{R}^{2}=0.744\right.$; SE est. 30.1$)$

Although within studies the relationship between digestibility and NDF or CP content was relatively strong, prediction of silage $\mathrm{D}$-value [g digestible OM $\left(\mathrm{kg} \mathrm{DM}^{-1}\right.$ ] from chemical composition during harvesting time will lead to substantial errors. Prediction errors of 32.8 and $30.1 \mathrm{~g} \mathrm{~kg}^{-1}$ are unacceptable for ration formulation. In practice, prediction errors are likely to be much greater since $\mathrm{N}$ fertilisation and other management factors are standardised better in research conditions. Improved methods for predicting silage D-value than that currently adopted based on grass $\mathrm{CP}$ and crude fibre content are urgently required. It is essential that silage D-value can be accurately predicted from a standing crop in order to reach an optimal balance between silage quality and DM yield. This is especially important at northern latitudes where the rates of changes in both DM yield and digestibility are very fast for first-cut swards. Surprisingly, the present data indicated that silage OMD could be more accurately predicted by number of days elapsed from May $1\left(R^{2}=0.845\right)$ than by chemical composition.

Total diet OM digestibility of grass silagebased diets can exceed $800 \mathrm{~g} \mathrm{~kg}^{-1}$ in growing cattle fed at the level between 70 to $80 \mathrm{~g} \mathrm{DM}$ per $\mathrm{kg}$ live weight $(\mathrm{LW})^{0.75}$ (Table 1). The proportion of grass silage was $700 \mathrm{~g}(\mathrm{~kg} \mathrm{DM})^{-1}$ and that of barley-rapeseed mixture (800:200) $300 \mathrm{~g} \mathrm{(kg}$ $\mathrm{DM})^{-1}$. Digestibility of cell wall carbohydrates was also very high indicating a high potential NDF digestibility. When determined by 12 day ruminal in situ incubation, potential NDF digestibility of grass cut at the recommended stage of maturity for silage can exceed $900 \mathrm{~g} \mathrm{~kg}^{-1}$ (Rinne et al. 1997, Huhtanen and Vanhatalo 1997). The decline in potential digestibility of NDF is slow at the beginning of the growing season but accelerates later (Huhtanen and Jaakkola 1994, Huhtanen and Vanhatalo 1997). In contrast, the rate of digestion declines faster at early stages of the growing season.

\section{Supplementation}

Owing to the high potential digestibility of grass silage and negative associative effects on digestion (refer to Mould 1988), OM digestibility of the total diet is not affected by the amount of concentrate supplements in dairy cows (Table 2). Only at a low level of supplementation did OM digestibility increase as expected, but at higher levels of supplementation OM and especially NDF digestibility slightly decreased when the amount of concentrate was increased. Reduced cell wall digestibility is partly due to adverse effects of low rumen $\mathrm{pH}$ on cellulolysis and partly to the intrinsic characteristic of silage and concentrate NDF the former generally being more digestible. As a result of negative associative effects on digestion, the increase in ME intake calculated from digestible OM (DOM) intake was markedly lower than that estimated from feed table values (Tuori et al. 1996). The ME content of incremental increases in DM intake was $10.6 \mathrm{MJ} \mathrm{kg}^{-1}$, i.e. only $73.5 \%$ of the predicted increase [14.5 $\mathrm{MJ}(\mathrm{kg} \mathrm{DM})^{-1}$ ]. Excluding the study using 3 and $6 \mathrm{~kg}$ of concentrate from the data, the ME content of incremental DM intake was only $9.8 \mathrm{MJ}(\mathrm{kg} \mathrm{DM})^{-1}$ or $68.4 \%$ of predicted increases.

Protein supplementation has often increased total diet digestibility, although dietary $\mathrm{CP}$ content has exceeded the level considered to be optimal for ruminal cell wall digestion (Oldham 1984). Supplementation with soya bean meal (SBM) increased total diet DM digestibility by $0.25 \mathrm{~g} \mathrm{~kg}^{-1}$ per $1 \mathrm{~g}$ increase in concentrate $\mathrm{CP}$ 


\section{AGRICULTURAL AND FOOD SCIENCE IN FINLAND}

Vol. 7 (1998): 219-250.

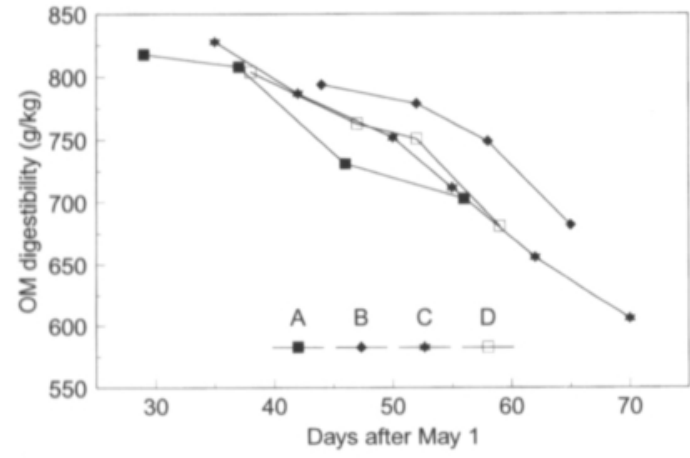

A

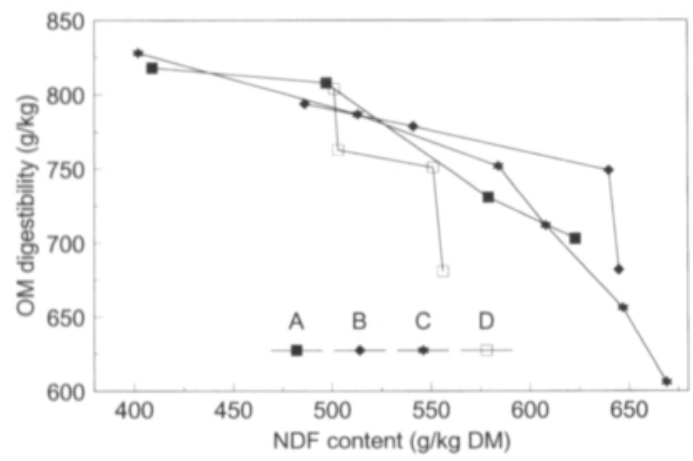

$\mathrm{C}$

content (Gordon et al. 1981), which corresponds to $0.60 \mathrm{~g} \mathrm{~kg}^{-1}$ per $1 \mathrm{~g}$ increase in dietary CP content. In contrast, supplementation of diets based on grass silage and cereal grains with rapeseed meal (RSM), which is the most common dairy cow protein supplement in Finland, had no ef-

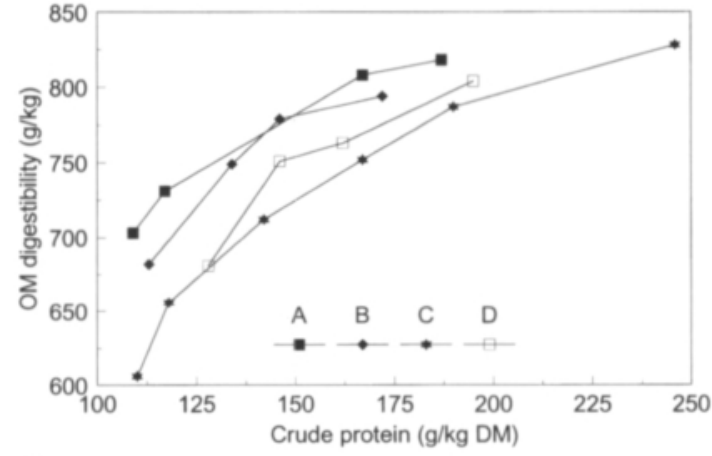

B

Fig. 1. Relationship between silage organic matter (OM) digestibility in sheep with days after May 1, crude protein and neutral detergent fibre (NDF) content. [Data from studies Rinne et al. $1995(\bullet), 1997(\mathbf{\square})$, unpublished $(\star)$ and Tuori et al. $1992(\square)]$.

fect on total OM $(0.723$ vs. 0.725$)$ or NDF digestibility ( 0.635 vs. 0.643$)$ in 13 comparisons. Since digestibility of RSM is lower than that of SBM, smaller responses to RSM than to SBM supplementation may merely reflect differences in protein supplement digestibility. Improved

Table 1. Digestibility of grass silage-based (700 $\mathrm{g}$ silage DM kg-1 total DM) diets in cattle.

\begin{tabular}{lccccc}
\hline Ref. & \multicolumn{2}{c}{ Composition $\left(\mathrm{g} \mathrm{kg}^{-1}\right)$} & \multicolumn{3}{c}{ Digestibility $\left(\mathrm{g} \mathrm{kg}^{-1}\right)$} \\
& CP & NDF & OM & NDF & Cellulose \\
\hline Khalili and Huhtanen 1991 & 183 & 501 & 813 & 774 & 846 \\
Jaakkola and Huhtanen 1992 & 179 & 484 & 837 & 824 & 869 \\
Rinne et al. 1997 & 187 & 409 & 821 & 757 & 818 \\
Rinne et al. 1997 & 167 & 497 & 816 & 765 & 821 \\
\hline
\end{tabular}

$\mathrm{DM}=$ dry matter

$\mathrm{CP}=$ crude protein

$\mathrm{NDF}=$ neutral detergent fibre

$\mathrm{OM}=$ organic matter 


\section{AGRICULTURAL AND FOOD SCIENCE IN FINLAND}

\section{Seminar in honour of the 100th anniversary of MTT}

Table 2. Effects of the amount of concentrate on diet digestibility and marginal increases in ME intake.

\begin{tabular}{|c|c|c|c|c|c|c|c|c|c|c|}
\hline \multirow[t]{2}{*}{ Ref. $^{1}$} & \multicolumn{2}{|c|}{ Concentrate $\left(\mathrm{kg} \mathrm{day}^{-1}\right)$} & \multicolumn{3}{|c|}{$\mathrm{OM} \operatorname{dig}\left(\mathrm{g} \mathrm{kg}^{-1}\right)$} & \multicolumn{3}{|c|}{ NDF dig $\left(\mathrm{g} \mathrm{kg}^{-1}\right)$} & \multirow{2}{*}{\multicolumn{2}{|c|}{$\begin{array}{l}\triangle \mathrm{ME} / \% \text { of } \\
\triangle \mathrm{DMI}^{2} \text { expected }\end{array}$}} \\
\hline & Low & High & Low & High & Change $^{4}$ & Low & High & Change $^{4}$ & & \\
\hline (1) & 3 & 6 & 684 & 699 & 5.0 & 658 & 635 & -7.7 & 14.06 & 93.7 \\
\hline (2) & 7 & 10 & 763 & 760 & -1.0 & 715 & 693 & -7.3 & 10.16 & 75.4 \\
\hline (3) & 7 & 10 & 715 & 712 & -1.0 & 665 & 629 & -12.0 & 9.78 & 76.5 \\
\hline (4) & 9 & 15 & 735 & 725 & -1.7 & 650 & 593 & -9.5 & 10.67 & 68.3 \\
\hline (5) & 6 & 12 & 746 & 725 & -3.5 & 670 & 589 & -13.5 & 8.42 & 53.5 \\
\hline Mean $^{5}$ & & & 729 & 724 & -0.43 & 672 & 628 & -10.00 & 10.62 & 73.5 \\
\hline Mean $^{6}$ & & & 740 & 731 & -1.79 & 675 & 626 & -10.58 & 9.76 & 68.4 \\
\hline
\end{tabular}

1 References: Saarisalo et al. 1997 (1), Rinne et al. 1995 (2), Shingfield et al. unpublished (3), Heikkilä 1994 (3), Heikkilä et al. $1998 b(5)$

2 Change in ME intake (MJ) per kg increase in total DM intake

${ }^{3}$ Change in ME intake (MJ) per kg increase in total DM intake as \% of expected increase calculated from feed table values or digestibility measurement determined in sheep

4 Change per $\mathrm{kg}$ increase in concentrate DM intake

5 Mean of all five studies

6 Mean of studies exluding study (1) in which a smaller amount of concentrate was used

$\mathrm{OM}=$ organic matter

$\mathrm{NDF}=$ neutral detergent fibre

$\mathrm{ME}=$ metabolisable energy

$\mathrm{DMI}=$ dry matter intake

OM digestibility with increasing level of fish meal inclusion (Heikkilä et al. 1998a) is in line with this suggestion.

\section{Feed intake}

Feeding levels of high producing dairy cows are 3-4 times higher than required for maintenance, i.e. much higher than that of other domesticated animals used for food production. Animal performance is determined mainly by intake of digestible energy (DE) and nutrients. A large proportion of the variation $(60-90 \%)$ in DE intake between animals and feeds can be accounted for by differences in feed intake. Only $10 \%$ to $40 \%$ of this variability is related to differences in digestibility (see Mertens 1994). Feed intake is regulated by physical and physiological mechanisms. Physiological regulation, often called metabolic regulation, operates when animals are fed highly digestible, palatable and low-fill diets and intake is limited by energy demand of animals. Physical factors regulate intake when the intake is limited by the physical capacity of the digestive tract (Mertens 1994).

\section{Digestibility}

Physical limitation of reticulo-rumen has generally been accepted to be the major factor limiting intake of forage diets. Thomas and Chamberlain (1982) suggested that physical factors regulate the intake of well-preserved highly digestible grass silages. The decrease in silage DM intake when water-filled bladders were inserted into the rumen (Farhan and Thomas 1978) supports this hypothesis. However, more recent data from rumen evacuation studies (Gasa et al. 1991, Bosch et al. 1992, Rinne et al. 1996) suggest that factors other than rumen fill limit the intake of early-cut highly digestible silages. Rumen fill in terms of total digesta, DM or NDF was smaller for cows fed early-cut than for those fed late-cut silage. Using digestion and passage kinetic parameters and rumen pool size of NDF derived from the study of Rinne et al. (1996) in a mechanistic rumen model (Huhtanen, unpublished) predicted that the intake potential of high digest- 


\section{AGRICULTURAL AND FOOD SCIENCE IN FINLAND}

Vol. 7 (1998): 219-250.

ibility silages (D-values 730 and $737 \mathrm{~g} \mathrm{DOM}(\mathrm{kg}$ $\mathrm{DM})^{-1}$ were 3.2 and $3.6 \mathrm{~kg} \mathrm{day}^{-1}$ higher than measured values in lactating dairy cows. Simulations were based on the assumption that intake of late-cut silage (D-value 637) was limited by rumen NDF fill. Analysis of data from production trials carried out at the University of Helsinki from 1985 to 1993 also suggests that energy demand was more likely to be limiting total DM intake than rumen fill. In all studies (47 diets), grass silage was fed ad libitum and concentrates comprised approximately $400 \mathrm{~g} \mathrm{~kg}^{-1}$ of the total DM. Regression equations indicate that increased DM intake provided almost all the extra energy required for higher milk production.

DM intake $(\mathrm{kg})=-9.68+0.0307 \times \mathrm{LW}(\mathrm{kg})+$ $0.407 \times$ milk $(\mathrm{kg})\left(\mathrm{R}^{2}=0.901\right)$

DM intake $(\mathrm{kg})=-10.10+0.0300 \times \mathrm{LW}(\mathrm{kg})+$ $0.421 \times \mathrm{ECM}(\mathrm{kg})\left(\mathrm{R}^{2}=0.929\right)$

In addition large increases in silage and total DM intake in feeding experiments during the past 20 years clearly suggest that the intake of grass silage-based diets has not been limited by rumen fill. For example, data of Heikkilä et al. (1998b) indicated that the highest mean silage DM intake of $16.0 \mathrm{~kg} \mathrm{day}^{-1}$ with $6 \mathrm{~kg} \mathrm{day}^{-1}$ of concentrate was higher than the total DM intake $\left(13.9 \mathrm{~kg} \mathrm{day}^{-1}\right)$ in studies carried out in 1970 1975 (Ettala et al. 1978). Data from milk recording from practical farms also indicate that mean milk yields exceeding 9000 to $10000 \mathrm{~kg} \mathrm{year}^{-1}$ from diets containing $35 \%$ of total DM intake as concentrates (Kaustell, K., unpublished).

Intake potential of grass silage is determined by intrinsic characteristics of the grass ensiled. Silage DM intake is positively related to digestibility, although this relationship is not always so clear as with dried forages. The mean increase in silage DM intake was $0.16 \mathrm{~kg}$ (SE 0.018) per $10 \mathrm{~g} \mathrm{~kg}^{-1}$ increase in D-value (Harrison et al. unpublished). Although the regression equation of Rook et al. (1991) suggested that the relationship between silage D-value and DM intake is curvilinear, other published studies (e.g. Rinne et al. 1995) indicate that this relationship is lin- ear up to $740 \mathrm{~g} \mathrm{~kg}^{-1}$. The large variation in the effects of silage D-value on intake can often be associated with differences in silage fermentation characteristics. Early-cut grasses are often more difficult to ensile due to a higher buffering capacity, and therefore the higher intake potential of an early-cut silage is not always realised due to poor fermentation quality. Improved digestibility and enhanced intake lead to an increase in total ME intake by ca. $0.3 \mathrm{MJ}$ per $1 \mathrm{~g}$ $\mathrm{kg}^{-1}$ increase in D-value. In addition to increased ME intake, utilisation of ME for milk production and energy retention have been reported to be higher with early-cut than late-cut silage (Gordon et al. 1995).

\section{Silage fermentation quality}

In addition to physical and physiological factors, psychogenic modifiers such as taste, smell, texture and visual appeal can influence feed intake (Mertens 1994). Modifications of carbohydrate and nitrogen fractions during ensiling produce fermentation end-products which decrease silage DM intake compared with fresh forages. Depressions in intake have been highly variable (1$64 \%$ ) in sheep (Demarquilly 1973). However, providing that the quality of fermentation is good, the effects of ensiling on intake are generally very small in cattle. In two recent studies (Keady and Murphy 1993) and Cushanan and Mayne (1995) the intake of FA-treated silage was not significantly lower than the intake of fresh forage. A review of Finnish and Swedish studies comparing barn-dried hay and FA-treated silage made from the same sward indicated no difference in forage DM intake (Huhtanen 1993b).

Variable effects of ensiling on forage DM intake are most likely to be related to extent and type of in silo fermentation. Earlier studies based on correlations calculated from individual observations (Wilkins et al. 1971, Ettala and Lampila 1978) clearly demonstrate the adverse effects of fermentation end-products on intake. Analyses of the Agricultural Research Centre of Finland (MTT) data by Huhtanen (1993b) using 49 treatment means from 14 dairy cow studies indicated that within an experiment the total acid 


\section{AGRICULTURAL AND FOOD SCIENCE IN FINLAND}

\section{Seminar in honour of the 100th anniversary of MTT}

content was the best predictor of silage DM intake. The effects of lactic acid, volatile fatty acids (VFA) and ammonia on silage DM intake were curvilinear. At low concentrations, lactate had a positive effect on silage intake. This is probably related to the secondary fermentation of some low lactate silages as indicated by high concentrations of ammonia and VFA. At higher concentrations, lactic acid had a negative effect on silage DM intake but there is little evidence that lactic acid per se limits intake since concentrations of ammonia and VFA are often increased in extensively fermented silages. Recent studies with wilted silage (Jaakkola et al. 1995, Heikkilä et al. 1998a) suggest that the effects of lactic acid are small provided that secondary fermentation and proteolysis are prevented. The effects of ammonia and VFA on silage DM intake appear to be curvilinear with greater depressions occurring at low concentrations (Huhtanen 1993b). Using a larger data set of 250 treatment means, Khalili et al. (unpublished) derived similar relationships between silage fermentation end-products and intake. Use of this larger dataset indicated that the linear effects of total acids and ammonia caused depressions in intake of $13.7 \mathrm{~g} \mathrm{DM}$ per $1 \mathrm{~g} \mathrm{(kg} \mathrm{DM})^{-1}$ and $14.3 \mathrm{~g} \mathrm{DM}$ per $1 \mathrm{~g}\left(\mathrm{~kg} \mathrm{~N}^{-1}\right.$. These values are lower than respective values of $24.7 \mathrm{~g}$ per $\mathrm{g}(\mathrm{kg} \mathrm{DM})^{-1}$ and $18.5 \mathrm{~g}$ DM per $1 \mathrm{~g}\left(\mathrm{~kg} \mathrm{~N}^{-1}\right.$ derived exclusively from Finnish data. The adverse effect of lactate on silage DM intake was smaller than that of VFA when both independent variables were used in the same model (11.9 and $21.4 \mathrm{~g}$ ).

The mechanism of silage DM intake depression with increasing concentrations of fermentation acids is not well understood. Reduced intake may simply be due to psychogenic factors, i.e. fermentation products, which impair silage 'palatability'. Silage fermentation products are also potential feed-back controllers of physiological intake regulation. Badly fermented silages decrease rumen motility (Clancy et al. 1977), which will induce a greater rumen fill at the same level of intake. Greater rumen NDF fill with one of the enzyme-treated silages than with FA-treated silage (Jaakkola et al. 1991) supports this suggestion. Higher intake of restrictively fermented than of extensively and/or badly fermented silage may also be associated with improved post-ruminal balance of amino acids to energy as a result of more efficient of rumen microbial $\mathrm{N}$ synthesis in the rumen. Positive effects of RSM supplementation and a greater effect of postruminal than ruminal casein infusion (Khalili et al. 1995a) tend to support this suggestion. However, the adverse effects of lactic acid on silage intake have not been overcome by postruminal casein infusion (Choung and Chamberlain 1993a) or by fish meal supplementation (Heikkilä et al. 1998a).

\section{Supplementation}

Grass silage is in most cases fed with energy and protein supplements. Energy supplements decrease silage DM intake but generally increase total DM intake. Ettala and Lampila (1978) reported a decrease of $0.64 \mathrm{~kg}$ in silage DM intake per $\mathrm{kg}$ increase in concentrate DM intake with a mean barley DM intake of $2.1 \mathrm{~kg}$. In a literature review (Ryhänen et al. 1996) involving 121 estimates of DM substitution rates (SR; decrease in silage DM intake per increase in concentrate DM intake) the mean SR was 0.39 with a high standard deviation (SD; 0.30). In recent studies at MTT mean SR in 16 comparisons was 0.53 (SD 0.12) when the amount of concentrate varied between 3 and $15 \mathrm{~kg}^{-1}$ day $^{-1}$. Generally, SR tends to increase with increases in concentrate intake, forage digestibility and silage fermentation quality. MTT data indicated that SR was 0.51 when the highest amount of concentrate did not exceed $10 \mathrm{~kg} \mathrm{day}^{-1}$ and 0.61 when it exceeded $10 \mathrm{~kg}$. The effects of silage D-value are not always consistent. Rinne et al. (1995) observed that SR was greatest with the lowest D-value silage. In a recent study, Shingfield et al. (unpublished) obtained SR values of $0.34,0.51$ and 0.41 for untreated, formic acid-treated and inoculated silage demonstrating the importance of silage fermentation.

Increasing concentrate $\mathrm{CP}$ content enhances silage DM intake. In studies with RSM, Tuori (1992) reported a mean increase of $0.027 \mathrm{~kg} \mathrm{si}$ - 


\section{AGRICULTURAL AND FOOD SCIENCE IN FINLAND}

Vol. 7 (1998): 219-250.

lage DM per $\mathrm{g} \mathrm{kg}^{-1}$ additional $\mathrm{CP}$ in the diet. In later studies reviewed for this paper, the corresponding response was 0.029 . These values are greater than the mean response of 0.012 observed for fish meal supplementation (Huhtanen 1993a, Heikkilä et al. 1998a) but similar to those reported for SBM for supplementation of grass silage and barley diets (Chamberlain et al. 1989). Marginal increases in ME intake are approximately $0.30 \mathrm{MJ}$ per $1 \mathrm{~g} \mathrm{~kg}^{-1}$ rise in dietary $\mathrm{CP}$ content. Increases in silage DM intake caused by protein supplementation have been suggested to result from a more efficient ruminal cell wall digestion (Oldham 1984) when the intake is limited by fill. However, as discussed before the effects of RSM on NDF digestibility are marginal at best, and cannot therefore explain increased silage intake. Greater intake responses would be expected with late-cut or low CP silages because on such diets the supply of rumen-degradable $\mathrm{N}$ is more likely to limit digestion. However, Rinne et al. (1995) noted that improvements in silage DM intake with RSM tended to be greater with early-cut than late-cut silages $\left(0.75,1.09,0.32\right.$ and $0.49 \mathrm{~kg} \mathrm{day}^{-1}$ for silages with D-values of 739, 730, 707 and 639, respectively). Duodenal casein infusion has been shown to increase silage DM intake more than ruminal infusion $\left(0.3 \mathrm{vs}\right.$. $\left.0.6 \mathrm{~kg} \mathrm{day}^{-1}\right)$ suggesting that post-ruminal metabolism may also influence DM intake (Khalili et al. 1995a). Rumen NDF fill was increased by duodenal infusion suggesting that rumen fill was not limiting in- take during ruminal infusions or that cows were able to increase capacity when the balance between amino acids and energy was improved. Cows given duodenal casein infusion also increased total chewing time despite spending 930 min day ${ }^{-1}$ chewing on control diets of silage alone (Khalili et al. 1995b). Small increases in silage DM intake with ruminal casein infusion were associated with a faster rate of ruminal NDF digestion.

\section{Rumen fermentation}

The rumen fermentation pattern in dairy cows given diets based on restrictively fermented silage is characterised by a small molar proportion of propionate and high molar proportions of acetate and/or butyrate in total VFA (Table 3). The ratios of acetate to propionate and that of acetate plus butyrate to propionate are very high, which may explain the high Finnish milk fat content $\left(44 \mathrm{~g} \mathrm{~kg}^{-1}\right)$. Variation in fermentation parameters is small supporting the suggestion of Chamberlain and Choung (1993) that with grass silage-based diets rumen fermentation pattern is mainly controlled by silage type. It is also noteworthy that despite high feeding levels of dairy cows, the molar proportion of propionate is not higher than that in growing cattle fed similar diets at a lower level of intake (e.g. Jaakkola and Huhtanen 1993, Jaakkola et al. 1993, Rinne et al. 1997).

Table 3. Pattern of rumen fermentation of dairy cows given diets based on restrictively fermented grass silage (data derived from Finnish studies).

\begin{tabular}{lllccc}
\hline & $\mathrm{N}$ & Mean & SD & Maximum & Minimum \\
\hline Acetate $\left(\mathrm{mmol} \mathrm{mol}^{-1}\right)$ & 34 & 665 & 20.2 & 696 & 624 \\
Propionate $\left(\mathrm{mmol} \mathrm{mol}^{-1}\right)$ & 34 & 165 & 10.9 & 187 & 142 \\
Butyrate $\left(\mathrm{mmol} \mathrm{mol}^{-1}\right)$ & 34 & 133 & 10.7 & 158 & 113 \\
A/P & 34 & 4.05 & 4.89 & 3.53 & 0.36 \\
$(\mathrm{~A}+\mathrm{B}) / \mathrm{P}^{2}$ & 34 & 4.85 & 0.38 & 5.73 & 4.23 \\
\hline
\end{tabular}

${ }^{1}$ Acetate / Propionate

${ }^{2}$ (Acetate + Butyrate) / Propionate 


\section{AGRICULTURAL AND FOOD SCIENCE IN FINLAND}

\section{Seminar in honour of the 100th anniversary of MTT}

Manipulating the proportions of rumen VFA in animals fed diets based on restrictively fermented grass silage is difficult. According to review of Huhtanen (1987a), increasing the proportion of barley-based concentrate from 0 to 750 $\mathrm{g}(\mathrm{kg} \mathrm{DM})^{-1}$ did not affect the proportion of propionate in rumen VFA, but acetate decreased and butyrate increased with supplementation level. Even at very high levels of supplementation [750 $\left.\mathrm{g}(\mathrm{kg} \mathrm{DM})^{-1}\right]$ molar proportions of propionate did not increase (Thomas et al. 1980, Jaakkola and Huhtanen 1993). Elevated butyrate with increased concentrate may be related to higher rumen protozoal numbers (Chamberlain et al. 1983, Jaakkola and Huhtanen 1993).

Replacing barley with unmolassed sugar beet pulp (Huhtanen 1988, Murphy et al. 1993) or barley fibre (Huhtanen 1992) and sometimes delaying the harvesting of grass for silage (Rinne et al. 1996, 1997) have increased propionate mainly at the expense of butyrate. These responses are rather unexpected since propionate tended to increase with dietary NDF content. In addition, these responses are, at least partly, associated with increases in protozoal number with diets containing less NDF. Replacing barley with oats (Vanhatalo et al. 1995a) or including RSM or SBM in the diet (Aronen and Vanhatalo 1992, Tuori et al. 1993) had no effects on rumen fermentation pattern, whereas large inclusions of rapeseed oil markedly enhanced ruminal propionate (Tesfa 1993), probably as a result of partial rumen defaunation.

Rumen fermentation pattern is greatly influenced by the extent of silage fermentation. A review of data from studies conducted on cattle showed a close positive relationship between the silage lactic acid concentration and the molar proportion of propionate in rumen VFA and a negative relationship between silage lactate and the lipogenic to glucogenic ratio in rumen VFA (van Vuuren et al. 1995). Similar relationships were found in sheep (Martin, P.A. et al. 1994). In their study, differences between silages in rumen fermentation pattern were maintained irrespective concentrate composition. The effects of lactate on ruminal propionate have been very consistent but water soluble carbohydrates (WSC) in restrictively fermented silages have sometimes increased acetate (Vanhatalo et al. 1992, Huhtanen et al. 1997a) and sometimes butyrate (Jaakkola et al. 1991, 1993). The reasons for different fermentation pattern of WSC are not known but it may be related to rumen methanogenic capacity, since contrary to butyrate production methanogenesis is a prerequisite of acetate (Demeyer and Van Nevel 1975). The effects of silage lactate and WSC on rumen fermentation patterns have been consistent with those observed when supplements of lactate (Jaakkola and Huhtanen 1992) or sucrose (Syrjälä 1972, Khalili and Huhtanen 1991) were given to animals fed silage-based diets.

\section{Protein supply}

Protein requirements of ruminant animals are met from two sources, microbial protein synthesised in the rumen and feed protein escaping rumen degradation. With grass silage and cereal grain-based diets microbial protein is the major source of amino acids absorbed from the small intestine, since CP of silage, barley and oat is rapidly and extensively degraded in the rumen. Despite larger contribution of microbial protein to the total supply of amino acids than that of undegraded feed protein, the main focus of protein evaluation has been on estimating ruminal protein degradability and intestinal digestibility of undegraded feed protein. This is probably due to nylon bag and mobile bag methods being handy tools to estimate these parameters. Studies of Varvikko (1986) and Vanhatalo (1995) have shown several problems with these methodologies. Less attention is paid to determining microbial protein production and factors influencing the efficiency of microbial protein synthesis (MPS), probably because the methods available for determining MPS are much more complicated, labour intensive and expensive. However, unless we can predict differences in the efficiency of MPS, limited real progress in protein rationing systems can be expected. 


\section{AGRICULTURAL AND FOOD SCIENCE IN FINLAND}

Vol. 7 (1998): 219-250.

It has often been claimed that the efficiency of MPS is lower in animals given silage diets than those fed fresh or dried forage, although there is little direct evidence to support this. Three reasons have been suggested for the lower efficiency of MPS with silage diets: a lower energy supply for rumen microbes from silage fermentation products than from WSC; an asynchronous release of energy and $\mathrm{N}$ from silage; and the nature of silage nitrogenous constituents (Thomas and Thomas 1985). Our studies examining the effects of silage additives have confirmed that the reduced supply of energy from silage fermentation products is the main reason for low efficiencies of MPS. Jaakkola et al. (1991) reported a lower efficiency of MPS for diets based on untreated or enzyme-treated silage than that based on formic acid treated silage. Gradual increase in FA application from 0 to 6 litres per tonne reduced the extent of in silo fermentation and proteolysis, which clearly increased microbial protein production from 49.0

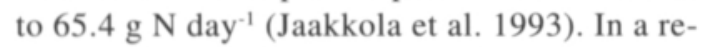
cent study by Huhtanen et al. (1997a), microbial protein production was $10 \%$ greater in cows given FA-treated silage than in those given inoculated silage. Intraruminal infusion of increasing amounts of lactic acid did not affect MPS (Jaakkola and Huhtanen 1992) indicating that lactic acid is of little or no value as an energy source for rumen microbes, which is in accordance with the theoretical considerations of Chamberlain (1987).

Jaakkola and Huhtanen (1992) compared the effects of barn-dried hay and FA-treated silage each fed with three levels of barley-based supplement on ruminal $\mathrm{N}$ metabolism. Efficiency of MPS [17.3 vs. $14.8 \mathrm{~g} \mathrm{~N}\left(\mathrm{~kg} \mathrm{DOM}^{-1}\right.$ ] was significantly higher with silage than hay diets. Duodenal feed protein flow tended to be greater with hay diets, which partially compensated for lower MPS. In three feeding experiments cows given silage-based diets produced on average $4.8 \%$ more milk protein than those given barn-dried hay made from the same grass sward (Heikkilä 1993). Both studies demonstrate that the protein value of restrictively fermented silage is not in- ferior to barn-dried hay. Suggestions of lower protein value of ensiled forages apply only to extensively and/or badly fermented silages.

Silage $\mathrm{N}$ is extensively degraded in the silo to peptides, amino acids and ammonia. Soluble $\mathrm{N}$ in silage is rapidly degraded in the rumen, whereas the amount of energy available is limited because of WSC fermentation. Therefore it was logical to conclude that asynchronous supplies of energy and $\mathrm{N}$ can limit the efficiency of MPS with silage diets. Syrjälä (1972) found that sucrose supplementation was more efficient than starch or cellulose in decreasing rumen ammonia concentration in sheep and attributed this to a faster release of energy from sucrose. Chamberlain et al. (1985) suggested that increases in rumen protozoal population and consequently, increased intraruminal recycling of $\mathrm{N}$ explains the less efficient utilisation of starchy supplements for ruminal MPS. Khalili and Huhtanen (1991) showed that sucrose supplementation was effective in decreasing rumen ammonia $\mathrm{N}$ and increasing MPS, but continuous infusion of sucrose stimulated MPS more than twice-daily feeding, despite the latter providing a more synchronous supply of energy and N. Feeding sucrose twice daily rapidly reduced rumen $\mathrm{pH}$ and increased lactic acid concentration. At low $\mathrm{pH}$ 'energy spilling' increases because rumen ATP is used to maintain intracellular $\mathrm{pH}$ at a higher level than in rumen fluid (Strobel and Russel 1986). In addition, the acrylate pathway provides much less energy for microbes than other pathways. Further, depression in cell wall digestion caused by a low mean $\mathrm{pH}$ decreases microbe energy supply. Chamberlain and Choung (1995) discussed the importance of synchronisation of energy and $\mathrm{N}$ release and concluded that there is no convincing evidence of a need for close synchronisation of energy and $\mathrm{N}$ release in the rumen to ensure efficient MPS. The best approach might be to attempt to achieve an even pattern of rumen energy supply (Henning et al. 1993).

In the data reviewed by Chamberlain and Choung (1995) the increase in MPS of $22 \mathrm{~g} \mathrm{~kg}^{-1}$ for carbohydrate supplements indicated that sugars had no additional value compared with mi- 


\section{AGRICULTURAL AND FOOD SCIENCE IN FINLAND}

\section{Seminar in honour of the 100th anniversary of MTT}

crobial protein production from the basal diet. However, the increase in the amount of fermentable substrate is overestimated owing to adverse effects of sugar supplements on ruminal digestion of the basal diet. The effects of sugar supplementation in the form of molasses have been disappointing both in lactating dairy cows (Huhtanen 1987b) and growing cattle (Huhtanen and Hissa 1996). From the previous discussion it can be concluded that asynchronous supply of energy and $\mathrm{N}$ from silage does not limit the efficiency of MPS.

Rumen ammonia concentrations of animals fed twice daily at restricted levels can be suboptimal for optimal microbial growth for extended periods of time. Therefore using protein supplements may improve the efficiency of MPS by providing a more constant supply of nitrogen for rumen microbes. However, the effects of protein supplementation on ruminal $\mathrm{N}$ metabolism are not conclusive. Substantial increases in rumen MPS with protein supplementation (Rooke et al. 1987, Rooke and Armstrong 1989) support the suggestion that when grass silage is supplemented with easily degradable carbohydrates, microbial growth is stimulated by additional amino acids and peptides. In contrast, RSM supplementation did not increase MPS in growing cattle (Aronen and Vanhatalo 1992) or lactating dairy cows (Ahvenjärvi et al. 1997). Bacteria digesting easily degradable carbohydrates in particular are considered to benefit from $\mathrm{N}$ in the form of amino acids and peptides (Russel et al. 1992). Increased MPS in response to ruminal casein infusion in cows given a diet based on red clover-grass silage as a sole feed (Khalili et al. 1995a) suggests that under some circumstances bacteria using forage carbohydrates can also benefit from supplementary high quality protein. Variable responses of protein supplements on ruminal MPS may be related to the form of soluble $\mathrm{N}$ in silage. For example, Jacobs and McAllan (1992) found a greater increase in MPS with supplementary RSM with enzyme- than FAtreated silage. The proportion of peptides is much higher in FA-treated than untreated or inoculated silage (Nsereko 1996). High marginal MPS
(38-58 $\mathrm{g} \mathrm{kg}^{-1}$ fermentable OM) responses to restricting in silo fermentation (Jaakkola et al. 1993) suggest that improvements of MPS associated with restriction of fermentation probably involve changes in $\mathrm{N}$ fractions as well as increases in the supply of sugars. These values are considerably greater than those reported for supplementary carbohydrates (Chamberlain and Choung 1995). However, when proteolysis was not increased in extensively fermented silage, the decrease in microbial $\mathrm{N}$ output could be entirely explained by decreases in fermentable OM (Huhtanen et al. 1997a).

It seems that the efficiency of MPS is highest when moderate amounts of concentrates are fed (Jaakkola and Huhtanen 1993). Increasing the proportion of concentrate in the diet from 250 to $500 \mathrm{~g} \mathrm{~kg}^{-1}$ enhanced MPS, whereas a further increase to $750 \mathrm{~g} \mathrm{~kg}^{-1}$ decreased it slightly. When moderate amounts of concentrates are fed, different sources of carbohydrates provide a more constant supply of energy maintaining rumen $\mathrm{pH}$ at optimal levels and avoiding wide fluctuations. The effects of the composition of energy supplements on MPS have been small. There was no difference between barley and unmolassed sugar beet pulp (SBP) in their effects on MPS and neither partial replacement of barley or SBP with sugar beet molasses did not influence MPS (Huhtanen 1988). Barley and oats had a similar effect on MPS when fed either with grass or red clover silage (Vanhatalo et al. 1995b). Replacement of barley with barley fibre decreased rumen protozoal number and increased the efficiency of MPS but not the duodenal flow of microbial protein (Huhtanen 1992). Similarly, supplementation of grass silage and barley diet with rapeseed oil decreased rumen protozoa and increased the efficiency of MPS but microbial N flow to duodenum was not increased, due to reduced ruminal OM digestibility (Tesfa 1993). The results of these two studies imply that improved efficiency of MPS cannot necessarily be interpreted as increasing the supply of amino acids when it is related to reduced OM digestion in the rumen.

Replacement of barley with fibrous by-prod- 


\section{AGRICULTURAL AND FOOD SCIENCE IN FINLAND}

Vol. 7 (1998): 219-250.

ucts such as unmolassed sugar beet pulp (Huhtanen 1988, Murphy et al. 1993) and barley fibre (Huhtanen 1992) increased the flow of feed protein escaping ruminal degradation. However, the quantity of amino acids absorbed from the small intestine was markedly changed due to higher faecal $\mathrm{N}$ output with fibrous supplements. RSM supplementation had no influence on microbial $\mathrm{N}$ flow in dairy cows, but the amount of feed protein escaping ruminal degradation increased significantly (Ahvenjärvi et al. 1997). Heat-moisture treated RSM did not increase either feed or total $\mathrm{N}$ flow compared with untreated RSM despite a large difference in ruminal $\mathrm{N}$ degradability determined by in situ incubations.

\section{Response to nutrients}

\section{Energy supply}

Rationing system used by the Finnish farmers advisory service proceeds from a desired milk production. This is used to calculate the feed input required to meet corresponding requirements. Generally, fixed and often restricted amounts of silage are fed while energy and protein supplements allocated according to milk yield. To optimise the profitability of milk production it is important to know the relationship between marginal changes in input and induced changes in animal performance.

Increasing the amount of concentrate in the diet is the most common strategy to increase energy intake and energy density of the diet. Marginal responses to increased concentrate supply and incremental ME differ considerably from theoretical values calculated from changes in input and average efficiencies of energy utilisation. In a large data set including 121 comparisons milk yield increased by $0.77 \mathrm{~kg}$ per $1 \mathrm{~kg}$ DM extra concentrate (Ryhänen et al. 1996). However, the responses were highly variable (SD $=0.54$ ) but markedly consistent for continuous and change-over experiments $(0.84$ vs. 0.77$)$. Marginal responses to additional concentrate decreased with the level of supplementation being $0.94,0.80$ and 0.60 when daily concentrate DM allowance was below 5.0, from 5.0 to 7.3 and above $7.3 \mathrm{~kg}$, respectively. However, marginal responses of 0.10 and $0.09 \mathrm{~kg}$ of milk and energy corrected milk (ECM) per MJ additional $\mathrm{ME}$ are considerably lower than $0.194 \mathrm{~kg} \mathrm{ECM}$ predicted from theoretical approaches (Tuori et al. 1996).

Marginal responses to increased amount of concentrate were evaluated from five recent studies conducted at MTT (Heikkilä 1994, Rinne et al. 1995, Saarisalo et al. 1997, Heikkilä et al. 1998b, Shingfield et al. unpublished). Data included 16 comparisons. Other factors, precisionchopped vs round- baled silages (Heikkilä 1994), silage digestibility (Rinne et al. 1995), level of RSM supplementation (Saarisalo et al. 1997), forage preservation method and silage fermentation (Shingfield et al. unpublished) and springand autumn-harvested silage (Heikkilä et al. 1998b), were also assessed. In all studies, total diet $\mathrm{OM}$ digestibility was determined using acid insoluble ash as an internal marker. ME intake was estimated using feed table values and as the product of $16\left(\mathrm{MJ} \mathrm{kg}^{-1}\right) \times(\mathrm{DOM}(\mathrm{kg})$. Data were further divided into low and high concentrate levels the latter including studies in which concentrate supplementation was 12 or $15 \mathrm{~kg} \mathrm{day}^{-1}$ (Heikkilä 1994, Heikkilä et al. 1998b). The other studies had concentrate levels of 3 to 6 and 7 to $10 \mathrm{~kg} \mathrm{day}^{-1}$.

The effects of concentrate supplementation on feed intake, milk yield and milk composition are shown in Table 4. The mean substitution rate was 0.53 (SD 0.12) and it was higher (0.61 vs. $0.51)$ at higher concentrate levels. Substitution rate in this data set was higher than the mean value of 0.39 based on the data of Ryhänen et al. (1996), which may also explain smaller production responses [0.56 (SD 0.19) vs. $0.77 \mathrm{~kg}$ milk per $1 \mathrm{~kg}$ extra concentrate DM]. Milk and ECM yield responses were lower at high $(0.45$ and $0.43)$ than low levels of concentrate $(0.60$ and 0.68). In earlier studies (Ettala et al. 1978) the 


\section{AGRICULTURAL AND FOOD SCIENCE IN FINLAND}

\section{Seminar in honour of the 100th anniversary of MTT}

Table 4. Effects of the level of concentrate supplementation on milk production. Data derived from studies of Heikkilä (1994), Rinne et al. (1995), Saarisalo et al. (1997), Shingfield et al. (unpublished), Heikkilä et al. 1998b).

\begin{tabular}{|c|c|c|c|c|c|c|}
\hline & \multicolumn{2}{|c|}{ High concentrate } & \multicolumn{2}{|c|}{ Low concentrate } & \multicolumn{2}{|c|}{ All data } \\
\hline & Low & High & Low & High & Low & High \\
\hline $\mathrm{N}$ & 4 & 4 & 12 & 12 & 16 & 16 \\
\hline \multicolumn{7}{|l|}{ Intake $\left(\mathrm{kg} \mathrm{DM}\right.$ day $\left.^{-1}\right)$} \\
\hline Concentrate & 6.72 & 11.57 & 5.03 & 7.63 & 5.45 & 8.61 \\
\hline Silage & 13.55 & 10.59 & 11.90 & 10.59 & 12.31 & 10.59 \\
\hline Total & 20.27 & 22.16 & 16.93 & 18.22 & 17.76 & 19.20 \\
\hline $\mathrm{ME}^{\prime}\left(\mathrm{MJ} \mathrm{day}^{-1}\right)$ & 225.1 & 254.2 & 191.8 & 209.5 & 200.1 & 220.6 \\
\hline $\mathrm{ME}^{2}\left(\mathrm{MJ}\right.$ day $\left.^{-1}\right)$ & 220.9 & 238.4 & 182.2 & 196.9 & 191.9 & 207.3 \\
\hline Milk yield $\left(\mathrm{kg} \mathrm{day}^{-1}\right)$ & 27.83 & 30.03 & 21.69 & 23.24 & 23.22 & 24.94 \\
\hline $\mathrm{ECM}$ yield $\left(\mathrm{kg} \mathrm{day}^{-1}\right)$ & 29.03 & 31.13 & 24.17 & 25.92 & 25.38 & 27.22 \\
\hline \multicolumn{7}{|c|}{ Milk composition $\left(\mathrm{g} \mathrm{kg}^{-1}\right)$} \\
\hline Fat & 44.0 & 42.8 & 49.9 & 49.4 & 48.4 & 47.8 \\
\hline Protein & 31.8 & 32.6 & 34.5 & 35.2 & 33.8 & 34.5 \\
\hline Lactose & 49.2 & 49.4 & 48.6 & 48.9 & 48.8 & 49.0 \\
\hline \multicolumn{7}{|l|}{ Yield $\left(\mathrm{g}_{\text {day }}-1\right)$} \\
\hline Fat & 1218 & 1281 & 1057 & 1128 & 1097 & 1166 \\
\hline Protein & 881 & 974 & 732 & 802 & 769 & 845 \\
\hline Lactose & 1369 & 1483 & 1053 & 1133 & 1132 & 1221 \\
\hline
\end{tabular}

${ }^{1}$ ME calculated from feed table values or digestibility measurements in sheep

${ }^{2}$ ME calculated as $16 \times$ DOM intake

$\mathrm{DM}=$ dry matter

$\mathrm{ME}=$ metabolisable energy

$\mathrm{ECM}=$ energy corrected milk

mean response to additional barley DM was 0.76 $\mathrm{kg}$ fat corrected milk (FCM) in cows producing $16 \mathrm{~kg} \mathrm{day}^{-1}$ and mean barley DM intake of $2.2 \mathrm{~kg}$ day $^{-1}$. It is generally assumed that high silage Dvalues and good fermentation quality are likely to increase substitution rate and reduce production responses to extra concentrate. However, marginal responses of $0.56,0.37$ and $0.62 \mathrm{~kg}$ with untreated, inoculated and FA-treated silage (Shingfield et al. unpublished) and 0.41, 0.46, 0.94 and $0.43 \mathrm{~kg}$ with silages of reducing D-value (Rinne et al. 1995) do not substantially support the possibility to compensate for the effects of reduced fermentation quality or digestibility by feeding more concentrates. In our trials the best responses $(0.86 \mathrm{~kg} \mathrm{ECM})$ to extra concentrate were obtained in late lactation of heifers producing only $14 \mathrm{~kg} \mathrm{milk} \mathrm{day}^{-1}$ (Saarisalo et al. 1997). This could be related to a lower diet di- gestibility and lower allocation of concentrate on the control diet $\left(3 \mathrm{~kg} \mathrm{day}^{-1}\right)$, but it also suggests that late-lactation cows can respond to increased supply of nutrients. The effects of increased concentrate feeding on milk composition were relatively small on milk fat content

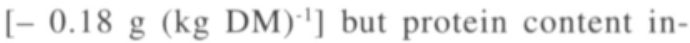

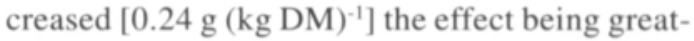
er at a low supplementation level $[0.26 \mathrm{vs} .0 .16 \mathrm{~g}$ $(\mathrm{kg} \mathrm{DM})^{-1}$ ].

Negative associative effect on digestibility is another factor helping to explain the small responses to additional concentrate. An ECM yield response of $0.093 \mathrm{~kg}$ per $\mathrm{MJ}$ additional $\mathrm{ME}$ is only $48 \%$ of that expected by theoretical approaches. In the present data, marginal responses were lower at high than low levels of concentrate allowance $(0.100 \mathrm{vs} .0 .073 \mathrm{~kg}$ per $\mathrm{MJ}$ additional ME). When ME intake was estimated from 
Vol. 7 (1998): 219-250.

Table 5. Partitioning of ME from additional concentrate given at high and low levels of supplementation. [ME contents of concentrates and silage were assumed to be 12.5 and $10.5 \mathrm{MJ}(\mathrm{kg} \mathrm{DM})^{-1}$ ].

\begin{tabular}{|c|c|c|c|c|c|c|}
\hline & \multicolumn{2}{|c|}{ Change } & \multicolumn{2}{|c|}{ High concentrate } & \multicolumn{2}{|c|}{ Low concentrate } \\
\hline & High & Low & MJ day ${ }^{-1}$ & (\%) & $\mathrm{MJ} \mathrm{day}^{-1}$ & (\%) \\
\hline $\begin{array}{l}\text { Concentrate }(\mathrm{kg} \mathrm{DM}) \\
\left(12.5 \mathrm{MJ} \mathrm{kg}^{-1}\right)\end{array}$ & 1.00 & 100 & 1250 & 1000 & 1250 & 1000 \\
\hline $\begin{array}{l}\text { Silage DM intake }(\mathrm{kg}) \\
\quad\left(10.5 \mathrm{MJ} \mathrm{kg}^{-1}\right)\end{array}$ & -0.61 & -0.50 & 6.38 & 51.1 & 5.31 & 42.5 \\
\hline $\begin{array}{l}\text { Negative associative } \\
\text { effects on digestion }\end{array}$ & & & 2.35 & 18.8 & 1.15 & 9.2 \\
\hline $\begin{array}{l}\text { Milk } \\
\qquad\left(5.2 \mathrm{MJ} \mathrm{kg}^{-1} \mathrm{ECM}\right)\end{array}$ & 0.43 & 0.68 & 2.25 & 18.0 & 3.50 & 28.0 \\
\hline $\begin{array}{l}\text { LW change } \\
\quad\left(1.0 \mathrm{MJ} \mathrm{kg}^{-1} \text { conc. DM }\right.\end{array}$ & & & 1.00 & 8.0 & 1.00 & 8.0 \\
\hline Unaccounted ${ }^{1}$ & & & 0.52 & 4.2 & 1.54 & 12.3 \\
\hline
\end{tabular}

${ }^{1}$ Errors in the estimation of LW change, reduced efficiency

$\mathrm{ME}=$ metabolisable energy

$\mathrm{DM}=$ dry matter

$\mathrm{ECM}=$ energy corrected milk

$\mathrm{LW}=$ live weight

DOM intake, the increases in ME intake in response to additional concentrate were markedly smaller than when estimates were based on feed table values. This difference can be attributed to a reduced efficiency of digestion (negative associative effects). As expected, deviations in ME intake estimated from DOM intake from that based on feed table values or sheep digestibility measurements were greater at high than low concentrate levels (11.4 vs. 3.0 $\mathrm{MJ}$ day $\left.^{-1}\right)$. True increases in ME intake were only $82.5 \%$ and $60.0 \%$ of calculated increase for low and high concentrate levels, respectively. Taking into account the negative associative effects on digestion, marginal ECM yield responses were increased to $0.125 \mathrm{~kg}$ per MJ additional ME at both levels of concentrate, i.e. $64 \%$ of expected response. These data suggest that a better response to extra concentrate at lower level of supplementation is associated with smaller decreases in silage intake and negative associative effects.

Partitioning of available energy between body tissues and mammary gland changes in favour of body tissues with increased concentrate allocation. Changes in body energy accounted for $1.0 \mathrm{MJ}$ per $\mathrm{kg}$ additional concentrate $\mathrm{DM}$ when estimated from LW change [34 MJ ME $(\mathrm{kg} \mathrm{LW})^{-1}$ ] in continuous trials (Heikkilä 1994, Heikkilä et al. 1998b). Table 5 shows the partitioning of ME from additional concentrate at two levels of concentrate supplementation. Reduced silage DM accounted for the largest proportion of additional ME derived from the concentrate at both levels. The contribution of additional milk yield and negative effects on digestion were similar at high concentrate levels, whereas at low concentrate inputs the contribution from milk was much greater. The proportion of additional ME accounted for by reduced silage DM intake, increased milk yield and negative associative effects in digestion were $79 \%$ and $88 \%$ at low and high concentrate levels, respectively. The remaining variation may be accounted for by LW change and reduced efficiency of energy utilisation, the former being a more likely explanation. It may be assumed that in practical conditions over several lactations the response to additional concentrate is greater than in feeding experiments, because of residual effects during the same lactation or subsequent lactations. However, field data from controlled herds in Finland indicated that the marginal response to additional 


\section{AGRICULTURAL AND FOOD SCIENCE IN FINLAND}

Seminar in honour of the 100th anniversary of MTT

Table 6. Selected treatment combinations from studies of Rinne et al. (1995) and Shingfield et al. (unpublished) to demonstrate the effects of forage quality on milk production.

\begin{tabular}{|c|c|c|c|c|}
\hline \multirow{3}{*}{$\begin{array}{l}\text { Reference } \\
\text { Forage } \\
\text { Supplement }\end{array}$} & \multicolumn{2}{|c|}{ Rinne et al. $1995^{1}$} & \multicolumn{2}{|c|}{ Shingfield et al. unpubl ${ }^{2}$} \\
\hline & High D & Low D & FA-treated & Untreated \\
\hline & $7 \mathrm{~kg} \mathrm{day}^{-1}$ & $10 \mathrm{~kg}^{-1}$ & $7 \mathrm{~kg} \mathrm{day}^{-1}$ & $10 \mathrm{~kg} \mathrm{day}^{-1}$ \\
\hline \multicolumn{5}{|l|}{ Intake (kg DM day $\left.{ }^{-1}\right)$} \\
\hline Concentrate & 6.16 & 8.90 & 6.20 & 8.86 \\
\hline Silage & 12.28 & 9.76 & 13.70 & 11.19 \\
\hline Total & 18.43 & 18.66 & 19.90 & 20.05 \\
\hline Milk yield (kg day $\left.{ }^{-1}\right)$ & 25.1 & 25.1 & 26.7 & 26.9 \\
\hline $\mathrm{ECM}$ yield $\left(\mathrm{kg}\right.$ day $\left.^{-1}\right)$ & 27.9 & 27.6 & 29.6 & 28.9 \\
\hline \multicolumn{5}{|c|}{ Milk composition $\left(\mathrm{g} \mathrm{kg}^{-1}\right)$} \\
\hline Fat & 49.1 & 48.3 & 49.0 & 45.9 \\
\hline Protein & 33.0 & 33.2 & 34.2 & 33.6 \\
\hline Lactose & 48.7 & 48.2 & 48.3 & 48.4 \\
\hline \multicolumn{5}{|l|}{ Yield $\left(\mathrm{g} \mathrm{day}^{-1}\right)$} \\
\hline Fat & 1226 & 1207 & 1290 & 1212 \\
\hline Protein & 821 & 826 & 908 & 898 \\
\hline Lactose & 1221 & 1209 & 1293 & 1294 \\
\hline \multicolumn{5}{|c|}{$\begin{array}{l}{ }^{1} \text { D-values of silages } 707 \text { (high D) and } 639 \text { (low D), CP content of concentrates } 124 \text { (high D) and } 155 \text { (low D) } \\
{ }^{2} \text { Composition of FA-treated and untreated silages }\left(\mathrm{g} \mathrm{kg}^{-1} \mathrm{DM}\right) \text { : water soluble carbohydrates } 62 \text { and } 22 \text {, } \\
\text { total acids } 51 \text { and } 118 \text { and ammonia } \mathrm{N}\left(\mathrm{g} \mathrm{kg}^{-1} \mathrm{~N}\right) 38 \text { and } 109 \text {, respectively. } \\
\text { DM = dry matter } \\
\text { ECM = energy corrected milk } \\
\text { FA = formic acid }\end{array}$} \\
\hline
\end{tabular}

concentrate was $0.11 \mathrm{~kg}$ milk per MJ ME (Kaustell et al. 1998), which is similar to values reported in feeding experiments.

Marginal responses to additional ME derived from increased digestibility of silage have been much higher than those obtained from additional concentrate. In the study of Rinne et al. (1995), marginal increases in ECM yield were 0.139 or 0.151 between silages of D-values of 739 and $639 \mathrm{~g} \mathrm{DOM}(\mathrm{kg} \mathrm{DM})^{-1}$, respectively. The former estimate is based on ME calculated from silage digestibility coefficients determined in sheep and from feed table values for concentrates. The latter is based on ME derived from DOM intake. In a similar study, Heikkilä et al. (1993) observed response of $0.173 \mathrm{~kg}$ per MJ additional ME (sheep digestibility and feed tables). True increases in ME intake are close to those expected when silage D-value was improved, which can account for the improved utilisation of additional ME from silage. The importance of forage qual- ity on the performance of dairy cows is demonstrated in Table 6. Performance of cows fed a high D-value (707) silage with $7 \mathrm{~kg} \mathrm{day}^{-1}$ grainbased concentrate $\left[124 \mathrm{~g} \mathrm{CP}(\mathrm{kg} \mathrm{DM})^{-1}\right]$ was similar to those fed a low D-value (639) silage with $10 \mathrm{~kg} \mathrm{day}^{-1}$ of RSM containing concentrate (155 $\mathrm{g} \mathrm{CP}$ ). Likewise, there were no differences in the performance of cows given FA-treated silage with $7 \mathrm{~kg} \mathrm{day}^{-1}$ and untreated silage with $10 \mathrm{~kg}$ day $^{-1}$ of concentrate. In these studies, mean responses to increased concentrate inclusion were 0.56 and $0.52 \mathrm{~kg} \mathrm{ECM} \mathrm{kg}^{-1}$ concentrate DM, respectively. Rinne et al. (1995) noted that a production response of $10 \mathrm{~g} \mathrm{~kg}^{-1}$ rise in silage Dvalue corresponded to $1.0 \mathrm{~kg}$ concentrate (fresh weight) and that the differences in response to silage fermentation quality between FA-treated and untreated silage were equivalent to $3.0 \mathrm{~kg}$ (fresh weight) of concentrate (Shingfield et al., unpublished).

Predicting milk output responses solely from 


\section{AGRICULTURAL AND FOOD SCIENCE IN FINLAND}

Vol. 7 (1998): 219-250.

increases in ME input is not easy. However, prediction accuracy can be improved if variations in forage quality, substitution rate, negative associative effects and nutrient partitioning are taken into account. When both the supply of ME and amino acids are manipulated, responses to ME can be different depending on the source of additional ME. To illustrate interactions between ME and amino acids absorbed from the small intestine (AAT), responses in ECM and protein yield to increments in nutrient supply are shown in Figure 2. Results are based on three studies, in which the effects of ME and AAT intake were studied in $2 \times 2$ factorial designs (Rinne et al. 1995, Saarisalo et al. 1997, Heikkilä et al. 1998b). ME intake was increased by feeding more concentrates and AAT intake by replacing grain with RSM. The four diets were low energy - low protein (LL), low energy - high protein (LH), high energy - low protein (HL) and high energy - high protein $(\mathrm{HH}) \mathrm{CP}$ intake from concentrate was similar for $\mathrm{LH}$ and $\mathrm{HL}$ diets. CP contents of the four diets were 138,161, 137 and

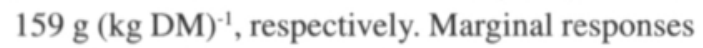
to additional ME derived from increased silage intake with high protein diets were almost threefold (mean 0.312) those obtained by increasing concentrate (mean 0.127). LH diets produced similar amounts of ECM to HL diets despite 9.6 $\mathrm{MJ}$ and $59 \mathrm{~g} \mathrm{day}^{-1}$ higher intakes of ME and AAT, respectively, for the latter. This suggests that provision of additional energy with a limited supply of amino acids is used with a low efficiency or partitioned towards body tissues. In contrast, enhancing the supply of amino acids the nutrients are partitioned more efficiently to milk production as indicated by higher marginal response to additional ME derived from increased silage DM intake than the theoretical value of $0.194 \mathrm{~kg} \mathrm{ECM} \mathrm{(MJ} \mathrm{ME)}{ }^{-1}$. Differential responses to additional ME may be accounted for by differences in ME utilisation or partition. Calorimetric studies have not confirmed that ME is used more efficiently (see Choung and Chamberlain 1993b) which suggests that energy is repartitioned with changes in protein supply. Although the difference in the utilisation of ad-

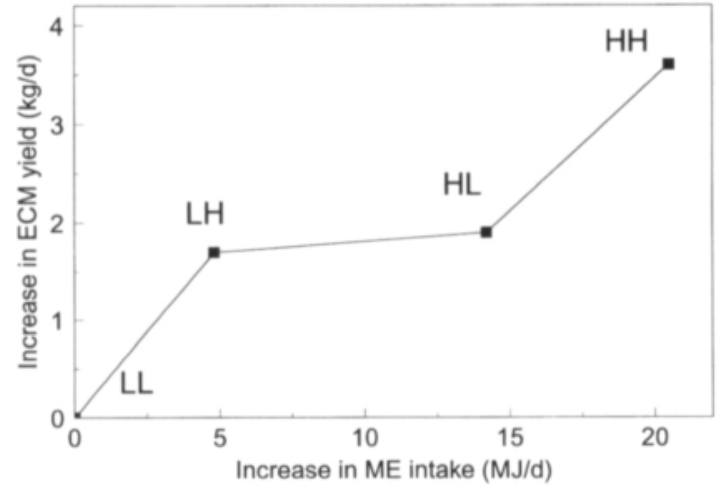

A

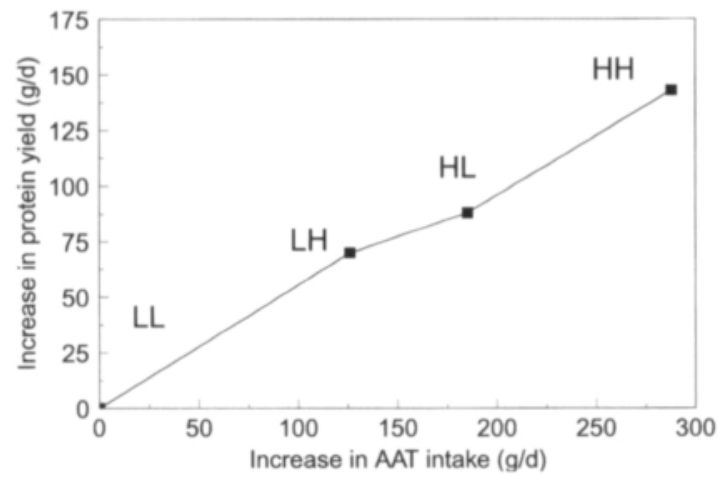

B

Fig. 2. Responses of energy corrected milk (ECM) yield to incremental increases in ME (above) and protein yield to incremental increases in amino acids absorbed in the small intestine (AAT) (below) when nutrient supply was increased by energy and protein supplementation. (Data from studies of Rinne et al. 1995, Saarisalo et al. 1997, Heikkilä et al. 1998b; Diet LL: low energy - low protein; LH: low energy - high protein; HL: high energy - low protein; $\mathrm{HH}$ : high energy - high protein).

ditional ME between energy and protein supplementation was large, an improvement of 0.025 0.030 in the efficiency of use ME available for milk production would account for this difference. Utilisation of incremental AAT supply was also lowest between diets LH and HL (0.31). However, the high ratio of ME to AAT of the incremental nutrient supply should improve the efficiency of AAT utilisation by enhancing the supply of glucose and other nutrients (Old- 


\section{AGRICULTURAL AND FOOD SCIENCE IN FINLAND}

Seminar in honour of the 100th anniversary of MTT

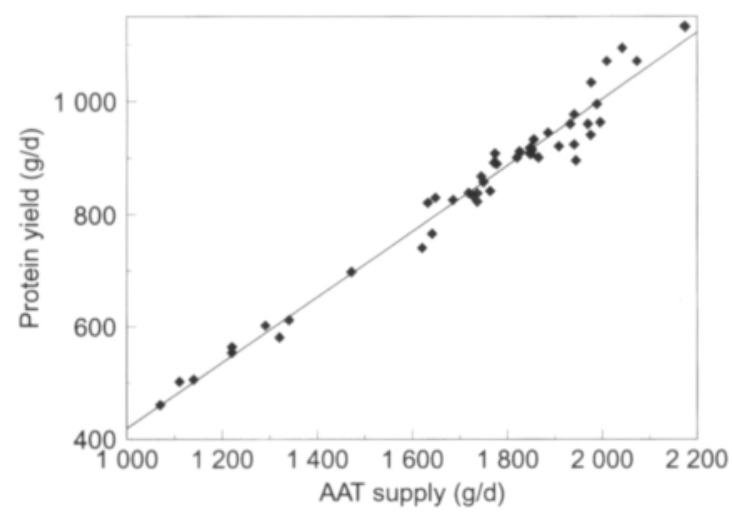

A

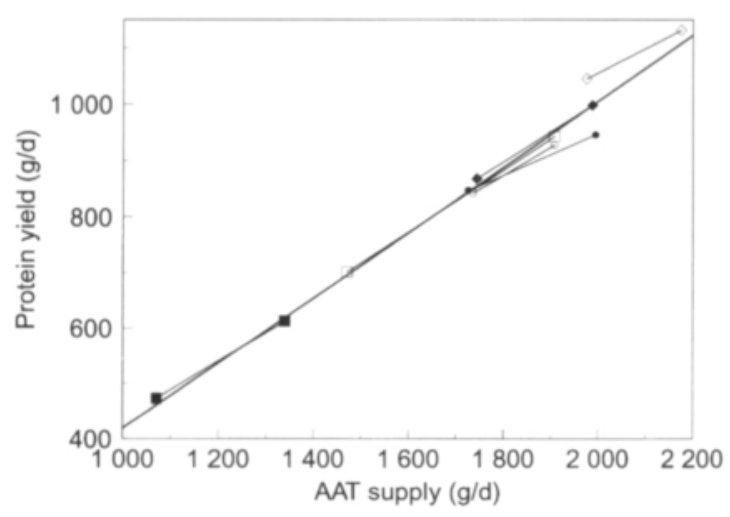

B

Fig. 3. Relationships between the supply of amino acids absorbed in the small intestine (AAT) and milk protein yield derived between (above) and within (below) experiments. [Data from studies of Rinne et al. 1995 ( $\square$ ), Huhtanen and Heikkilä (o) 1996, Saarisalo et al. 1997 (四); Heikkilä et al. 1998a $(\diamond)$, Rinne et al. $1998(\diamond)$, Shingfield et al. unpublished (O).

ham 1994). In contrast, incremental AAT was utilised more efficiently ( 0.56 and 0.53$)$ when increases in ME supply were relatively small between diets $\mathrm{LL}$ and $\mathrm{LH}$ and diets $\mathrm{HL}$ and $\mathrm{HH}$, respectively.

\section{Protein supply}

\section{Protein evaluation}

Protein evaluation in Finland was based on digestible CP until 1995 when a modification of the Scandinavian AAT - PBV (protein balance value in the rumen) was adopted. The strategy for being self-sufficient in protein feeding and meeting protein requirements of dairy cows in the 1960s and 1970s was to feed silages of high CP supplemented with barley. High CP content of silage was achieved by applying high levels of $\mathrm{N}$ fertilisers and early cutting. This approach often resulted in inefficient protein utilisation, since the recovery of additional $\mathrm{N}$ obtained by increased $\mathrm{N}$ fertilisation is completely lost from the rumen (Vanhatalo and Toivonen 1993) and that obtained by earlier cutting is only partially recovered in duodenum (Rinne et al. 1997). At that time, the strategy based on very high $\mathrm{CP}$ content of silage was not really challenged by feeding high quality protein supplements.

The details of the Finnish AAT-PBV system are described by Tuori et al. (1998). The main differences from the Nordic system (Madsen et al. 1995) are the calculation of microbial protein production on the basis of digestible carbohydrates and rumen degradable protein and using slower passage rate values of feed particles to calculate rumen effective protein degradation. In studies conducted after the AAT-PBV system was adopted in Finland, the relationship between AAT supply calculated using feed table values (Tuori et al. 1996) and milk protein yield has been very close (Fig. 3). Protein responses were linear within experiments and the slopes (about 0.50 ) were not very different from a mean slope of 0.58 . Root mean square error of protein yield predicted from AAT intake was only $27 \mathrm{~g}$. In a similar survey, Webster (1992) noted that slopes between experiments was close to the theoretical utilisation of metabolisable protein but within experiments, marginal responses were rather small and very different from the mean slope. Linear responses similar to the mean slope, in contrast to data of Webster (1992), clearly suggest that utilisation of additional protein is very high and that Finnish requirements may be too low. Around the requirements productive traits tend to follow the law of diminishing returns.

The accuracy of protein evaluation system may also be estimated by comparing marginal 


\section{AGRICULTURAL AND FOOD SCIENCE IN FINLAND}

Vol. 7 (1998): 219-250.

protein yield responses to incremental AAT. When the amount of concentrate in the diet is increased, calculated supply of AAT rises as a result of higher feed intake and higher AAT content in typical barley-based concentrates than in grass silage. In five studies conducted at MTT, mean protein yield responses were $0.416 \mathrm{~g}$ (g AAT $)^{-1}$. Smaller responses than mean or within experiment slopes suggest that the protein value of energy supplements is overestimated. This may be due to negative associative effects in digestion leading to overestimation of the true increase in energy supply for rumen microbes. Lower rumen $\mathrm{pH}$ and reduced efficiency of MPS at higher levels of concentrate supplementation may also be involved in a lower apparent utilisation of incremental AAT intake with increased concentrate supplementation. When AAT supply was increased by replacing energy supplements with RSM in 13 comparisons, a higher marginal response $(0.551)$ was obtained than that achieved by feeding more energy supplements. The value is similar to the slope of regression in the whole data set indicating that our protein system accurately predicts the relative protein value of RSM.

When AAT supply was increased by earlier cutting of silage or by improving silage fermentation quality, marginal responses to incremental AAT were much higher. Incremental AAT supply obtained by earlier harvesting of grass for silage resulted in a marginal response of 0.84 (Heikkilä et al. 1993). In the study of Rinne et al. (1995), the corresponding response was 0.59 between four silages harvested at different stages of growth, which was upgraded to 0.78 when the earliest cut silage was excluded from the data. Very high apparent marginal responses (1.091.19) to incremental AAT supply were obtained in two recent studies (Jaakkola et al. 1996, Shingfield et al., unpublished) when silage fermentation quality was improved. These data suggest that the protein value of high digestibility and well-preserved silages are underestimated in relation to concentrates, and that the AAT-PBV system underestimates the incremental increases in AAT supply when forage quality is improved. This could be associated with fixed values assigned to the efficiency of MPS to calculate AAT values. Improving silage fermentation quality has clearly improved the efficiency of MPS as discussed previously and also tend to be improved with higher D-value of silages (Rinne et al. 1997, Rinne et al. unpublished).

\section{RSM supplementation}

RSM is the most common protein supplement used in dairy cow diets in Finland. In recent studies it has produced considerable production responses when used to replace energy supplements in the concentrate. The mean response in 13 comparisons was $1.05 \mathrm{~kg}$ milk and $39.4 \mathrm{~g}$ milk protein per one kg RSM as fed basis (Table 7). Treatments to reduce ruminal protein degradability RSM have not produced any further responses in milk yield compared with untreated RSM (Tuori 1992, Huhtanen and Heikkilä 1996, Rinne et al. 1998). RSM also slightly increased milk protein content $\left(0.5 \mathrm{~g} \mathrm{~kg}^{-1}\right)$ but only $15 \%$ of the milk protein yield response can be attributed to the change in milk protein content. Marginal increases in milk and protein yield per one gram increase in $\mathrm{CP}$ intake were similar to those reported by Chamberlain et al. (1989) with SBM supplementation of grass silage and barley diets. Although RSM supplementation increases silage DM intake, additional ME intake does not fully account for the increased milk yield. The mean increase in ECM yield of $0.35 \mathrm{~kg}$ per MJ ME in studies of Rinne et al. (1995), Huhtanen and Heikkilä (1996), Saarisalo et al. (1997) and Rinne et al. (unpublished) is much higher than corresponding responses of 0.09 to increased levels of concentrate supplementation (Ryhänen et al. 1996) or that based on theoretical considerations of 0.194 (Tuori et al. 1996). A higher apparent efficiency of utilisation of incremental ME with RSM supplementation indicates that either efficiency of energy utilisation is improved with a more balanced supply of amino acids and/or nutrients are partitioned towards the mammary gland. An increase in milk yield of $1.45 \mathrm{~kg}$ per $100 \mathrm{~g}$ increase in AAT intake with RSM supplementation is much higher than $0.50 \mathrm{~kg} \mathrm{FCM}$ per $100 \mathrm{~g}$ additional PDI (protéines digestibles dans 
Seminar in honour of the 100th anniversary of MTT

Table 7. The effects of replacing the energy supplement in the concentrate supplement with rapeseed meal in cows given grass silage-based diets. Data include 12 comparisons derived from Huhtanen et al. 1995, Rinne et al. 1995, Huhtanen and Heikkilä 1996, Jaakkola et al. 1996, Ahvenjärvi et al. 1997, Saarisalo et al. 1997, Heikkilä et al. 1998b).

\begin{tabular}{|c|c|c|c|c|}
\hline & $\begin{array}{c}\text { Control } \\
\text { (No RSM) }\end{array}$ & $\begin{array}{c}\text { RSM } \\
(2.0 \mathrm{~kg} \mathrm{RSM})\end{array}$ & $\begin{array}{c}\text { Change per } \\
\text { kg RSM }\end{array}$ & $\begin{array}{c}\text { Change per g } \\
\mathrm{kg}^{-1} \text { diet } \mathrm{CP} \text { content }\end{array}$ \\
\hline \multicolumn{5}{|l|}{ Intake } \\
\hline Silage (kg DM day $\left.{ }^{-1}\right)$ & 10.92 & 11.42 & 0.247 & 0.025 \\
\hline Total $(\mathrm{kg} \mathrm{DM}$ day-1) & 17.67 & 18.29 & 0.318 & 0.027 \\
\hline Crude protein $\left(\mathrm{g} \mathrm{day}^{-1}\right)$ & 2408 & 2911 & 250 & \\
\hline $\operatorname{AAT}\left(\mathrm{g} \mathrm{day}^{-1}\right)$ & 1564 & 1708 & 71.6 & \\
\hline Diet crude protein $\left(\mathrm{g} \mathrm{kg}^{-1)}\right.$ & 136 & 159 & 11.4 & \\
\hline Milk yield (kg day ${ }^{-1)}$ & 23.92 & 26.02 & 1.05 & 0.092 \\
\hline Protein content $\left(\mathrm{g} \mathrm{kg}^{-1}\right)$ & 32.3 & 32.8 & 0.23 & 0.023 \\
\hline Protein yield $\left(\mathrm{g} \mathrm{day}^{-1}\right)$ & 763 & 841 & 39.4 & 3.44 \\
\hline Milk urea $\left(\mathrm{mg} 100 \mathrm{ml}^{-1}\right)$ & 19.9 & 28.5 & 4.0 & 0.374 \\
\hline OM digestibility $\left(\mathrm{g} \mathrm{kg}^{-1}\right)$ & 723 & 725 & 1.0 & 0.107 \\
\hline NDF digestibility $\left(\mathrm{g} \mathrm{kg}^{-1}\right)$ & 635 & 643 & 4.0 & 0.309 \\
\hline
\end{tabular}

l'intestin) (Vérité et al. 1997) implying that additional protein from RSM was used efficiently. High marginal responses to additional AAT also suggest that the supply of amino acids from the basal diet of silage and energy supplements is suboptimal.

Milk protein yield responses to RSM supplementation at $0.156 \mathrm{~g} \mathrm{~g}^{-1}$ increase were similar to those observed with fish meal supplementation (0.153) in four comparisons of Huhtanen (1993a) and Heikkilä et al. (1998a). Responses to RSM were not related to $\mathrm{CP}$ content of the basal diet $(\mathrm{r}=0.11)$. In a similar comparison of SBM and fish meal, Chamberlain et al. (1989) reported that the relative value of SBM was about $80 \%$ of that of fish meal. In a comparison of RSM and SBM, Tuori (1992) found that RSM had at least the same value as SBM as a protein supplement for dairy cows. In our studies with postruminal casein infusions marginal increases in milk protein yield of $0.288 \mathrm{~g} \mathrm{~g} \mathrm{~g}^{-1}$ were markedly higher than that of RSM. In eight comparisons, casein infusion (mean $285 \mathrm{~g}$ day $^{-1}$ ) increased milk yield (21.1 vs. $\left.22.9 \mathrm{~kg} \mathrm{day}^{-1}\right)$, protein content (33.5 vs. $\left.34.6 \mathrm{~g} \mathrm{~kg}^{-1}\right)$ and protein yield (703 vs. $788 \mathrm{~g}$ day $\left.{ }^{-1}\right)$. The effect on milk protein content was much greater with casein than with RSM $(0.5$ vs. $1.1 \mathrm{~g} \mathrm{~kg}^{-1}$ ), and since milk lactose slightly decreased with casein infusion (49.1 vs. $48.7 \mathrm{~g}$ $\left.\mathrm{kg}^{-1}\right)$, its infusion increased the yield of milk protein more than lactose ( $\left.85 \mathrm{vs} .80 \mathrm{~g} \mathrm{day}^{-1}\right)$.

\section{Factors affecting protein response}

In general, it appears that the magnitude of production responses to protein supplementation is not related to the level of concentrate supplementation, CP content of silage or production level of the control diet. Rinne et al. (1995) and Heikkilä et al. (1998b) observed no differences in milk protein yield response when similar amounts of RSM were used to replace grain at concentrate levels of 7 and 10 or 6 and $12 \mathrm{~kg}$ day $^{-1}$. In contrast to these studies, Saarisalo et al. (1997) reported a that increases in milk protein yield in first lactation cows given $6 \mathrm{~kg}_{\text {day }}{ }^{-1}$ of concentrates were smaller than that in cows given $3 \mathrm{~kg} \mathrm{day}^{-1}$ (48 vs. $\left.93 \mathrm{~g} \mathrm{day}^{-1}\right)$. A higher 


\section{AGRICULTURAL AND FOOD SCIENCE IN FINLAND}

Vol. 7 (1998): 219-250.

Fig. 4. Relationship between silage crude protein content and protein supplementation responses. [Data from studies Heikkilä et al. 1993 (ש), Rinne et al. 1995 (•), Heikkilä et al. 1998b (口), Jaakkola et al. unpublished ( $\star$ ); RSM was fed at $0.8,1.2,2.0$ and $2.0 \mathrm{~kg}$ day $^{-1}$, respectively].

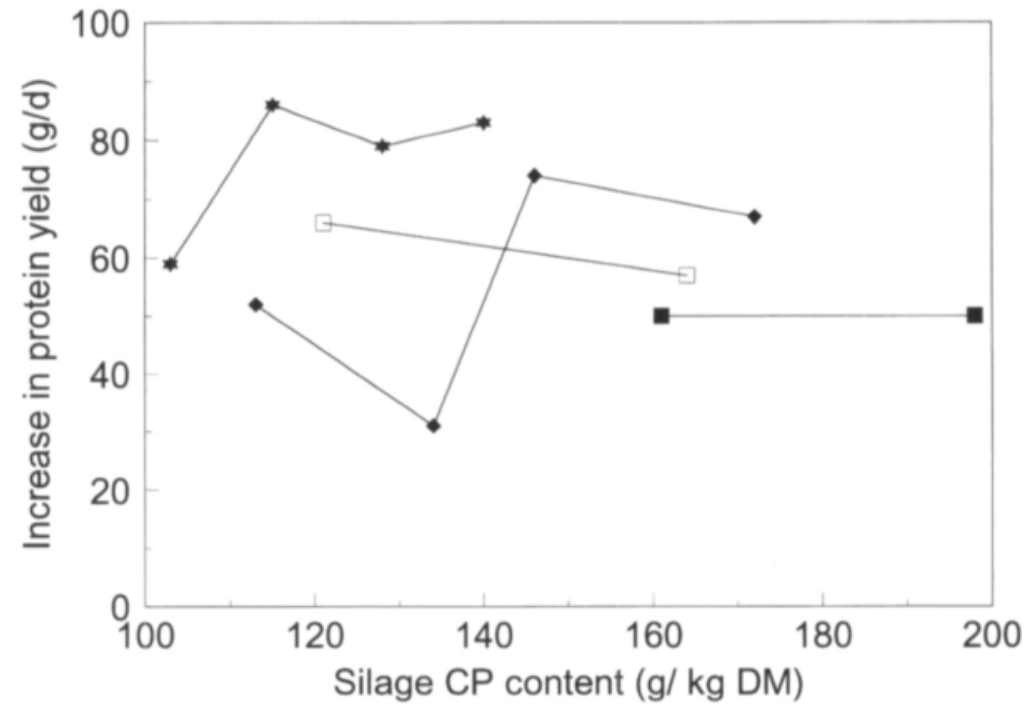

increase in silage DM intake at lower level of concentrate is likely to account for larger increases in protein yield. In other studies RSM has produced similar silage intake and protein yield responses at low and high levels of concentrate (Rinne et al. 1995, Heikkilä et al. 1998b).

Traditionally it has been expected that the rates of responses to protein supplementation are greater when the CP content in silage is low and MPS is limited by N supply for rumen microbes. However, inclusion of RSM in the diet has produced similar increases in milk protein yield over a wide range of silage CP contents (Fig. 4). On the basis of these observations it can be argued that calculated PBV can be from -15 to $-20 \mathrm{~g}$ per kg DM without adversely affecting MPS. Likewise, lack of responses to urea or RSM supplementation in omasal or duodenal flow of microbial $\mathrm{N}$ in cows fed a basal diet containing $127 \mathrm{~g} \mathrm{CP}\left(\mathrm{kg} \mathrm{DM}^{-1}{ }^{-1}\right.$ (Ahvenjärvi et al. 1997) also supports the suggestion that the $\mathrm{N}$ requirements of rumen bacteria can be satisfied by relatively low dietary CP content.

The magnitude of protein yield responses to RSM supplementation is not related to production level (Fig. 5). Since the amount of RSM varied between studies, responses were scaled to $2 \mathrm{~kg} \mathrm{RSM} \mathrm{day}^{-1}$ assuming a linear relation- ship between RSM inclusion and protein yield. This assumption is supported by linear increases in protein yield from 0 to $3 \mathrm{~kg} \mathrm{RSM} \mathrm{day}^{-1}$ (Rinne et al., unpublished). Regression of protein yield against RSM and control diets was parallel with $\mathrm{y}=\mathrm{x}$ (slope 0.994 ) but had a positive intercept of $87 \mathrm{~g}$. This implies that relative increases are higher in low- than high-producing cows. Marked increases in milk protein yield of low-producing cows have also been reported with postruminal casein infusions (Choung and Chamberlain 1993b) and fish meal supplementation (Chamberlain et al. 1992). There are several reasons which explain production responses to increased supply of amino acids in lowyielding cows. Due to slower passage rates of digesta the efficiency of MPS is decreased and ruminal degradability of feed protein increased with lower levels of intake in less productive cows. The efficiency of MPS was on average $17.4 \mathrm{~g}$ $\mathrm{N}(\mathrm{kg} \mathrm{DOM})^{-1}$ for 39 diets in growing cattle fed at the level of $70-80 \mathrm{~g} \mathrm{DM}(\mathrm{kg} \mathrm{LW})^{-0.75}$ in studies conducted at the Universtity of Helsinki using a marker technique to estimate duodenal digesta flow. The corresponding value estimated from urinary purine derivative excretion in cows eating $17-18 \mathrm{~kg} \mathrm{DM} \mathrm{day}^{-1}$ was $24.0 \mathrm{~g} \mathrm{~N}^{-1}$ $(\mathrm{kg} \mathrm{DOM})^{-1}$ for 18 diets in studies carried out at 


\section{AGRICULTURAL AND FOOD SCIENCE IN FINLAND}

\section{Seminar in honour of the 100th anniversary of MTT}

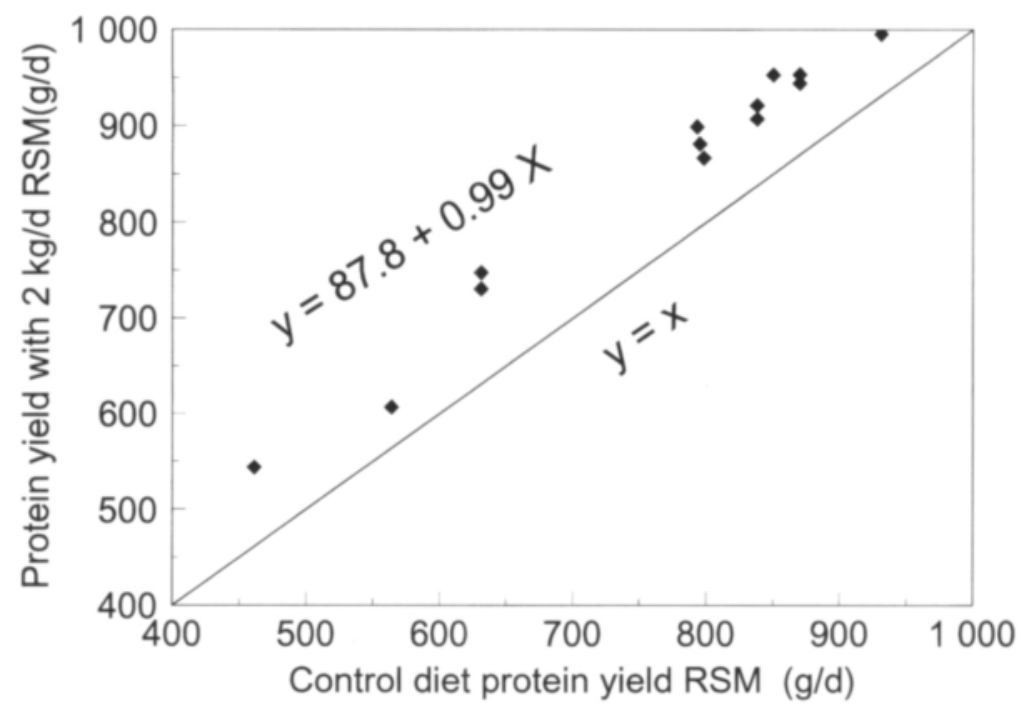

Fig. 5. Relationships between milk protein yield and responses to rapeseed meal (RSM) supplementation.
MTT. These results emphasise the importance of feeding level on the efficiency of MPS, although some differences may be associated with methodological problems encountered in MPS measurements. Higher efficiencies of MPS and reduced ruminal degradability of feed protein imply that the ratio of amino acids and ME at tissue level increases with level of feeding and therefore requirements of protein supplementation between low and high producers are smaller than that calculated based on traditional ration formulation schemes. Similar milk and protein yields in cows given the same amount of protein in concentrate as high-low, medium-medium and low-high strategies in early and midlactation (Aston et al. 1994) also suggest that there is no advantage of feeding more protein in early than mid-lactation.

Large positive responses in low-producing cows to supplementary protein may be associated with increased partitioning of nutrients for milk production. Similar ECM yield in cows given $3 \mathrm{~kg} \mathrm{day}^{-1}$ of high protein concentrate and in those given $6 \mathrm{~kg} \mathrm{day}^{-1}$ of a low protein grain supplement despite $13 \mathrm{MJ}$ day $^{-1}$ higher ME intake with the latter (Saarisalo et al. 1997) suggest that the risks of excessive fattening during late lactation may be reduced with protein supplementation. High responses to postruminal casein infusion in cows receiving excessive amounts of energy and protein in relation to requirements (Choung and Chamberlain 1993b) also provides evidence partitioning effects of increased amino acid supply.

Increases in milk protein yield in low-producing late-lactation cows or in cows of positive AAT balance may also be associated with imbalances in amino acids absorbed from the small intestine. To evaluate this hypothesis, calculations of amino acid balance were conducted. Two diets consisting of grass silage and barley (SB; 600:400 $\mathrm{g} \mathrm{kg}^{-1}$ ) on DM basis) or grass silage, barley and rapeseed meal (SBR; 600:320:80 on DM basis) were fed to meet ME requirements. Amino acid supply was calculated according to the AAT-PBV system (Tuori et al. 1996) with exception that MPS was calculated using a value of $24 \mathrm{~g} \mathrm{~N}(\mathrm{~kg} \mathrm{DOM})^{-1}$. It was assumed that $80 \%$ of microbial $\mathrm{N}$ flow was bacteria and $20 \%$ protozoa. The supply of amino acids from microbial $\mathrm{N}$ was estimated using amino acid composition of bacteria derived from Storm and Ørskov (1983) and protozoa from Martin, C. et al. (1994). Undegraded feed pro- 


\section{AGRICULTURAL AND FOOD SCIENCE IN FINLAND}

Vol. 7 (1998): 219-250.

tein amino acids were calculated using rumen degradability values and amino acid composition documented in Finnish feed tables (Tuori et al. 1996). Undegraded feed protein was assumed to have the same amino acid composition as the original feed. A value of $0.35 \mathrm{~g} \mathrm{~N}(\mathrm{~kg} \mathrm{LW})^{-0.75}$ was used for maintenance requirement (AFRC 1992) and it was assumed that the amino acid profile for maintenance is similar to that in bovine tissue. Calculations are based on the assumption that mixtures of ideally balanced amino acids are utilised with an efficiency of 0.90 .

Balances of the supply and requirements of total AAT and some individual amino acids are shown in Fig. 6. The SBR diet satisfied the needs of AAT for maintenance and milk production, whereas SB diet supplied sufficient AAT for cows producing up to $15 \mathrm{~kg} \mathrm{day}^{-1}$. Both diets met lysine requirements at all production levels. Methionine became limiting when milk yield exceeded 20 and $30 \mathrm{~kg} \mathrm{day}^{-1}$ for SB and SBR diets, respectively. According to the present calculations methionine was not, however, the first limiting amino acid, since histidine became limiting for the two diets at 15 and $25 \mathrm{~kg}$ milk production, respectively. These calculations are consistent with our amino acid infusion studies. Post-ruminal infusions of increasing amounts of methionine or lysine did not lead to changes in milk and protein yields (Varvikko et al. 1997), whereas histidine significantly enhanced milk protein yield (Vanhatalo et al. 1997, Huhtanen et al. 1997b). A limited supply of histidine may explain production responses in studies with lowproducing cows (Saarisalo et al. 1997) when AAT requirements were met. Owing to a low feeding level, deficiency of histidine may be accentuated since the efficiency of MPS is likely to be lower than that used in the model. Positive responses at higher level of RSM than used in the present calculations (Rinne et al., unpublished) may also be associated with a limited supply of histidine despite satisfying AAT requirements. Calculations suggest that in high-producing cows the supply of leucine and/or phenylalanine + tyrosine may also become limiting.

\section{Glucose supply}

Although restricting grass in silo fermentation improves silage protein value, limited supply of glucose may limit the utilisation of amino acids. Rumen fermentation pattern rich in acetate and butyrate and low in propionate in animals given diets based on restrictively fermented silages does not provide sufficient precursors for gluconeogenesis. Lower plasma glucose concentration in cows given restrictively fermented silage than in those given high lactate silages (Miettinen and Huhtanen 1997, Heikkilä et al. 1998b, Shingfield et al. unpublished) may indicate that the supply of glucose from these diets is limited. To illustrate the glucogenic potential of diets based on restrictively fermented silage, the supply from different precursors was calculated based on stoichiometric principles. SBR diet described previously was used to meet ME requirements at different production levels. Based on the assumptions that the proportion of OM digested apparently in the rumen was 0.70 and mean VFA proportions were acetate 665 , propionate 165 and butyrate $133 \mathrm{mmol} \mathrm{mol}^{-1}$ (Table 3) estimates of VFA production were calculated. These estimates also assumed that VFA were produced in the same proportions as present in the rumen or that the absorption rates of propionate and butyrate are $20 \%$ higher than that of acetate. In this case, molar proportions estimated by a simulation model were 626,187 and $151 \mathrm{mmol} \mathrm{mol}^{-1}$. Complete conversion of propionate to glucose on molar basis was also assumed. The extent of amino acid catabolism was estimated as amino acids absorbed minus amino acids secreted as milk protein. A maximum conversion rate of $100 \mathrm{~g}$ amino acids to yield $55 \mathrm{~g}$ glucose was used. A third net source of glucose, derived from starch digestion in the small intestine, was estimated assuming that $10 \%$ of starch intake escaped rumen fermentation and that $50 \%$ of absorbed starch was recovered as glucose in the liver. A maintenance requirement of glucose

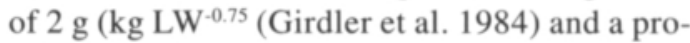
duction requirement of $70 \mathrm{~g} \mathrm{~kg}^{-1}$ milk (Danfær 1994) were used. 


\section{AGRICULTURAL AND FOOD SCIENCE IN FINLAND}

Seminar in honour of the 100th anniversary of MTT

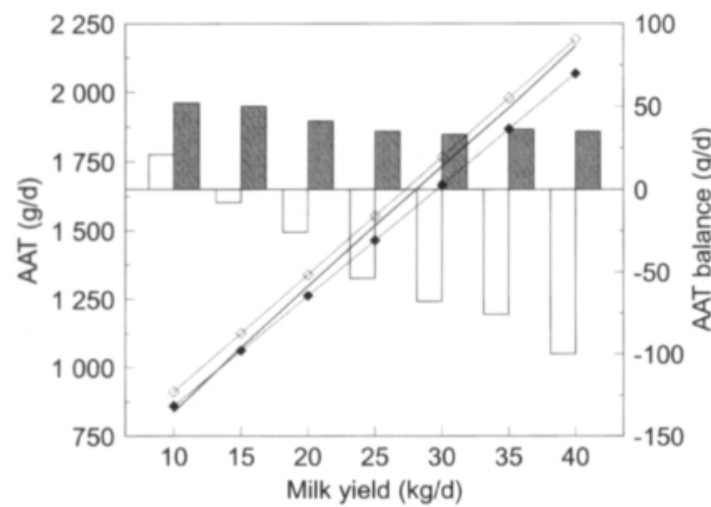

A

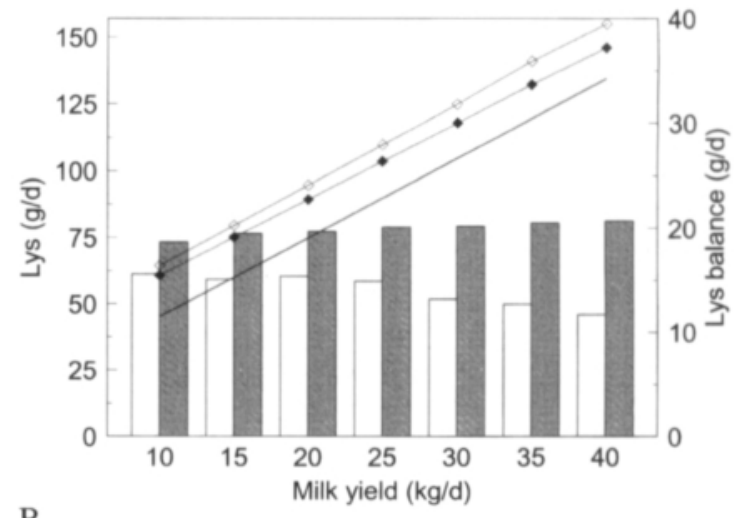

B

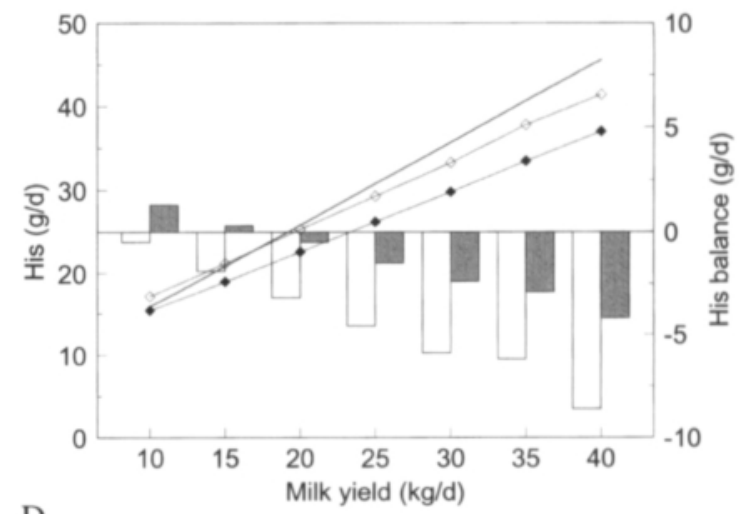

D
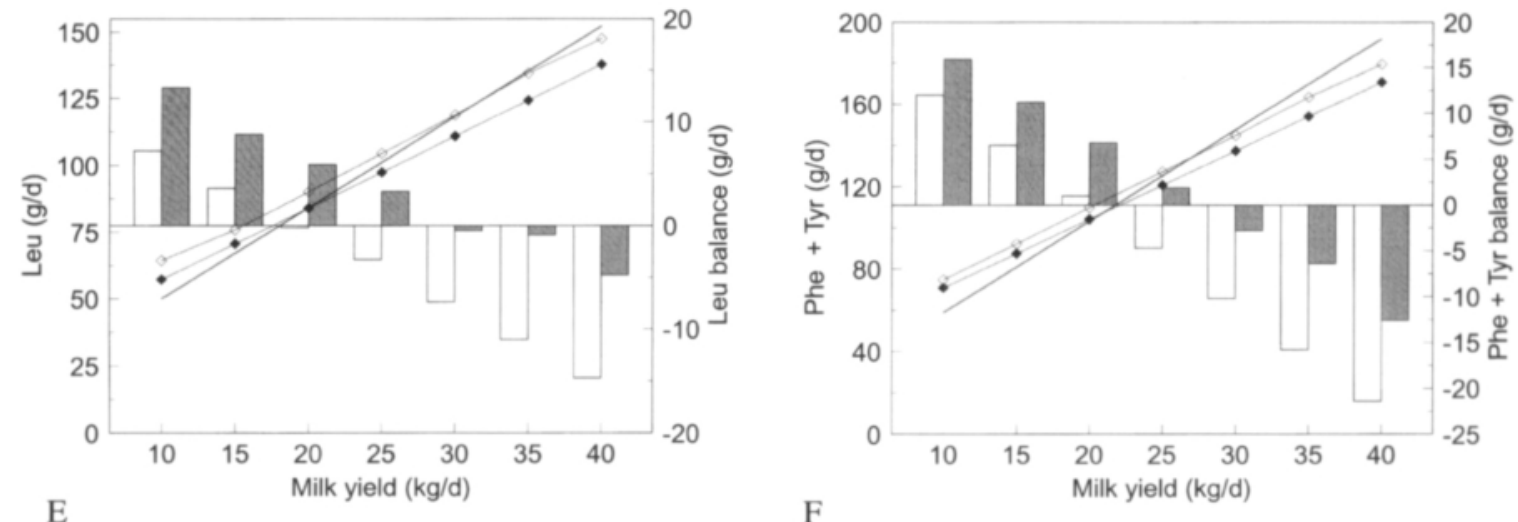

Fig. 6. Estimated requirements, supply and balance of amino acids absorbed in the small intestine (AAT), and some amino acids from two diets. [Requirement: solid line; supply from silage-barley (SB; 600-400 on DM basis) diet: dashed line with -; supply from silage-barley-RSM (SBR; 600-320-80) diet: dashed line with $\diamond$; Balance with SB diet open bars; balance with SBR diet dashed bars]. 


\section{AGRICULTURAL AND FOOD SCIENCE IN FINLAND}

Vol. 7 (1998): 219-250.

Theoretical calculations of glucose supply and requirement at different production levels of cows fed to meet ME requirements are shown in Fig. 7. If the proportions of VFA present in the rumen are equal to production, the supply of glucose appears to be suboptimal when milk yield exceeds 20 or $25 \mathrm{~kg} \mathrm{day}^{-1}$ with the both methods of computation. Glucose supply from branchedchain VFA and propionate production in the hind-gut were not taken into account, but quantitatively these are of minor importance. However, a high coefficient of ruminal OM digestion $(0.70)$ and maximum conversion rates for amino acids and propionate were used. The greatest uncertainty is how reliably ruminal VFA ratios predict true proportions of VFA production. If glucose is limiting, more amino acids are used for gluconeogenesis reducing the efficiency of amino acid utilisation for milk protein synthesis. Although incremental amounts of amino acids may not represent a large proportion of gluconeogenesis, its influence on the amount of amino acids available for protein synthesis can be considerable. When the supply of amino acids increases without a change in other energy yielding nutrients, additional amino acids need to be catabolised to maintain a constant lactose to protein ratio in milk (Oldham 1994). Oldham suggested that under these circumstances the maximum conversion of metabolisable protein to milk protein is 0.25 . Interestingly, mean conversion rates of incremental protein to milk protein in our casein infusion studies, 0.286 , are very close to this value. Although a proportion of this response may be mediated through increased $\mathrm{N}$ retention, a low efficiency of utilisation of incremental protein may be due to catabolism of amino acids to produce glucose necessary for lactose synthesis.

Two examples can be given of interactions between amino acid and glucose metabolism. The effects of RSM and wet distillers' solubles (WDS) on milk protein yield were additive in cows given a grain-based concentrate. RSM and WDS increased protein yield by 55 and $52 \mathrm{~g}^{\text {day }}{ }^{-1}$ when given alone and by $99 \mathrm{~g} \mathrm{day}^{-1}$ when combined (Huhtanen et al. 1995). With a supplement

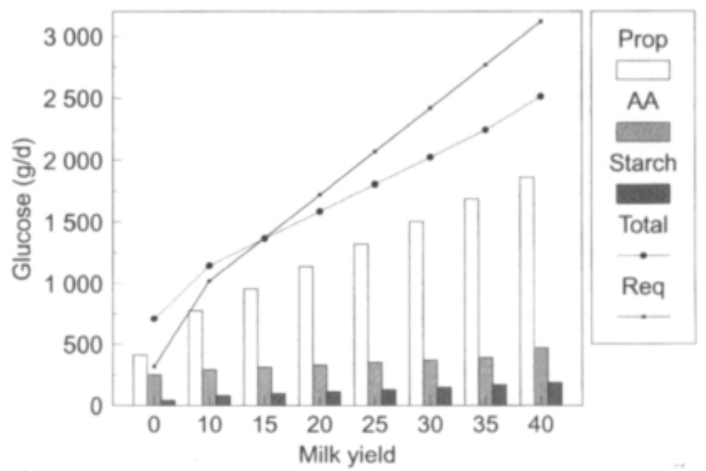

A

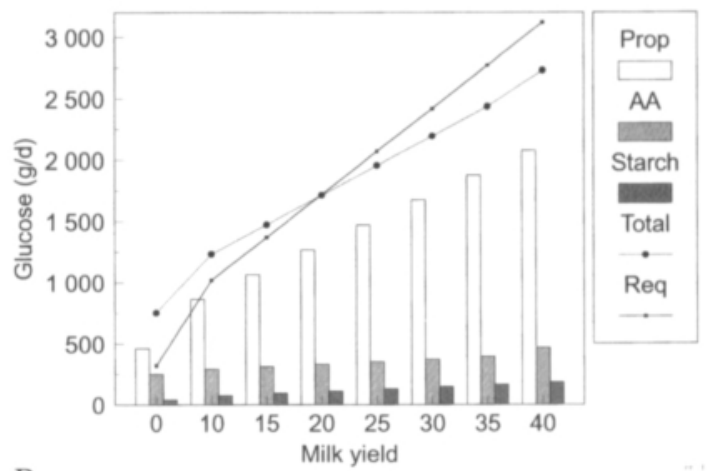

B

Fig. 7. Estimated requirements and supply of glucose from different precursors. Rates of volatile fatty acid (VFA) production were estimated assuming that production was similar proportions in the rumen (above) or that absorption of propionate and butyrate were $20 \%$ greater than acetate.

containing fibrous by-products the corresponding increases were 73,19 and $72 \mathrm{~g} \mathrm{day}^{-1}$, respectively. WDS probably increased protein yield with a starchy supplement through increased gluconeogenesis from WDS lactate, which is mainly fermented to propionate in the rumen. In a study with cannulated animals WDS did not increase duodenal $\mathrm{N}$ flow (Huhtanen 1992) and therefore would not increase amino acid supply. In a postruminal infusion study, both glucose and histidine alone increased milk protein yield (15 and $29 \mathrm{~g} \mathrm{day}^{-1}$ ) but the increase was $57 \mathrm{~g} \mathrm{day}^{-1}$ when infused together (Huhtanen et al. 1997b). With histidine alone, glucose production was 


\section{AGRICULTURAL AND FOOD SCIENCE IN FINLAND}

\section{Seminar in honour of the 100th anniversary of MTT}

Table 8. Effects of glucose supplementation given either as a ruminal infusion of propionate or a postrumínal infusion of glucose. Data derived from Miettinen and Huhtanen 1996 (P + PB vs. BP +B), Huhtanen et al. 1997a, 1998, Vanhatalo et al. unpublished.

\begin{tabular}{|c|c|c|c|c|c|c|c|}
\hline & \multirow[t]{2}{*}{ Milk (kg day $\left.{ }^{-1}\right)$} & \multicolumn{3}{|c|}{ Milk composition $\left(\mathrm{g} \mathrm{kg}^{-1}\right)$} & \multicolumn{3}{|c|}{ Component yield $\left(\mathrm{g}\right.$ day $\left.^{-1}\right)$} \\
\hline & & Fat & Protein & Lactose & Fat & Protein & Lactose \\
\hline \multicolumn{8}{|l|}{ Diet } \\
\hline Low glucose & 23.2 & 43.9 & 32.1 & 46.5 & 1001 & 739 & 1074 \\
\hline High glucose & 24.1 & 41.4 & 32.3 & 47.0 & 981 & 771 & 1129 \\
\hline Difference & +0.9 & -2.5 & +0.2 & +0.6 & -20 & 32 & 55 \\
\hline
\end{tabular}

probably limiting lactose synthesis leading to amino acid catabolism, whereas responses to glucose alone were possibly limited by the first limiting amino acid.

The effects of increasing glucose supply on milk protein yield by either manipulating the profile of VFA infused into the rumen or by postruminal glucose infusion have been variable, but in most cases are positive. Data from studies investigating the effects of glucose supply with grass silage-based diets is shown in Table 8. Glucose supply was manipulated either by VFA ruminal infusions (propionate vs. butyrate) or by abomasal glucose infusion. Increasing the proportion of propionate at the expense of butyrate lead to better responses than glucose infusion. This may be related to higher milk production and therefore glucose requirements and to the fact that supplementary protein feeding in VFA infusion studies provided more amino acids for increased milk protein secretion. In addition, butyrate may have reduced the efficiency of the utilisation of propionate for gluconeogenesis thereby reducing glucose supply further. In practical feeding it is very difficult to increase propionate production in cows given diets based on restrictively fermented silage. For example, production responses with supplements of propylene glycol (Jaakkola et al. 1996, Shingfield et al. unpublished) or glycerol (Khalili et al. 1997) were not promising. Increments in the yield of lactose have been markedly greater than that of protein when glucose supply has been increased. The ratio of the increments in protein and lac- tose yield (PL ratio) was only 0.48 , whereas the corresponding ratios with RSM or casein supplementation were considerably higher at 0.99 and 1.15 , respectively. Low PL ratio with glucose supplementation would suggest that one or more amino acids limited milk protein secretion under these circumstances. However, a low PL ratio in incremental yields with protein supplementation may indicate a shortage of glucose leading to increased amino acid catabolism. Duodenal casein infusion produced a higher PL ratio with inoculant than FA-treated silage (1.55 vs. 0.89) in the study of Huhtanen et al. (1997a). Likewise, the PL ratio was higher ( 0.95 vs. 0.76 ) when RSM was given in combination WDS rather than fed alone (Huhtanen et al. 1995). In both cases glucose supply was likely to be higher with the diets eliciting a higher PL ratio. Further work is needed to elucidate the interaction between amino acids and glucose, because minimising the catabolism of amino acids for glucose production would improve the efficiency of utilisation for milk protein secretion and reduce $\mathrm{N}$ losses to the environment.

\section{Conclusions and future aspects}

In Finland, lower temperatures and longer days than at lower latitudes together with grass varieties adapted to northern latitudes produce a grass with a high-digestibility with a DM yield poten- 


\section{AGRICULTURAL AND FOOD SCIENCE IN FINLAND}

Vol. 7 (1998): 219-250.

tial almost two-fold greater than that of cereal grains. Good ensiling technology and the use of efficient silage additives preserve grass for long winter feeding periods without extensive nutrient losses. Addition of high levels of acids tends to increase effluent losses compared with untreated or inoculant silages, which needs to be prevented. In Finland, relative advantages of forage-based feeding systems are probably one of the highest providing that subsidy systems do not bias feed prices.

For ration formulation more accurate predictions of silage D-value from the standing crop are urgently needed. Changes in digestibility are extremely rapid at northern latitudes and not accurately predicted by the chemical composition of grass. Harvesting either too early or too late can present economic losses in terms of reduced DM yield or nutritive value, respectively. Production experiments have demonstrated that it is difficult to compensate for the effects of low D-value in silage by feeding additional concentrate. Approximately $1 \mathrm{~kg}^{\mathrm{day}}{ }^{-1}$ additional concentrate is required to compensate for a decrease of $10 \mathrm{~g} \mathrm{~kg}^{-1}$ in silage D-value, which typically occurs within 2 days. Using meteorological data available from weather stations and measurements of changes in D-value by NIR techniques may provide better tools to optimise harvesting time.

Traditionally in Finland, grass has been ensiled using high rates of FA application (4 to 5 litres per tonne). Typically theses silages con-

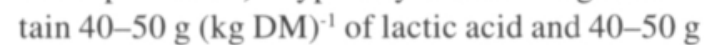
$(\mathrm{kg} \mathrm{N})^{-1}$ of ammonia $\mathrm{N}$. Losses in nutritive value during ensiling are extremely limited, and are not higher than that of barn-dried hay harvested from the same sward. Measurements of digestibility, ruminal protein metabolism, feed intake and production responses in lactating dairy cows all suggest that restrictively fermented silage has at least the same nutritive value as barn-dried hay produced from the same sward. Our studies suggest that a lower protein value of ensiled forages than of fresh or dried forages applies only to badly and/or extensively fermented silages.

Although the protein value and intake poten- tial of restrictively fermented silages are higher than those of extensively fermented silages, available nutrients are not well balanced for milk protein production. The pattern of rumen fermentation in animals given diets based on restrictively fermented silages is characterised by small molar proportion of propionate and high molar proportions of lipogenic VFA. Due to limited gluconeogenesis from propionate, more amino acids are required for glucose production. This can compromise higher protein values of restrictively fermented compared with extensively fermented silages, which tend to produce more propionate in the rumen. The pattern of rumen fermentation in animals given restrictively fermented silage is resistant to manipulation, since it is controlled mainly by silage type. For example, increasing the amount of barley-based concentrate has proved to be inefficient. Imbalanced amino acid composition may also explain why the higher protein value of FA-treated silage is not fully realised in production experiments. Further studies are needed to evaluate the effects of amino acid supplementation and interactions between amino acid and glucose metabolism.

Marginal responses to additional concentrate have been relatively small in recent studies, especially at higher levels of supplementation. High substitution rates of highly digestible wellfermented silages and moderate amounts of concentrate are likely to explain the smaller responses to additional concentrates than has been generally reported. Total diet digestibility does not increase with increased concentrate inputs, and therefore incremental increases in ME intake are generally smaller than expected. Although we could estimate the true increment in ME intake, variation in the partitioning of additional ME between mammary gland and body tissues creates a further problem in attempting to predict milk production responses. There are large differences in the apparent efficiency of utilisation of additional ME provided by additional concentrate, improved silage digestibility or increased silage DM intake in response to protein supplementation. More research is needed to understand the effects of and the interactions between 


\section{Seminar in honour of the 100th anniversary of MTT}

nutrients on energy utilisation and partitioning.

Supplementation of grass silage-based diets with RSM, SBM or fish meal has consistently produced considerable responses indicating that the supply of amino acids from silage and grain diets is either quantitatively or qualitatively limited. Protein yield responses can be accurately predicted from changes in AAT supply suggesting that our protein evaluation system can adequately evaluate typical diets used in Finland.
High marginal responses to additional AAT in milk protein and ECM yield indicate that supplementary protein is used efficiently and that the present feeding recommendations are rather low. Production responses are not related to production level, stage of lactation, amount of concentrate, silage CP content or total diet CP indicating that simpler protein feeding strategies can be applied in practice than currently used in the present ration formulation system.

\section{References}

AFRC 1992. Nutritive requirements of ruminant animals: Protein. Technical Committee on Responses to Nutrients, Report No. 9. (Agricultural and Food Research Council). Nutrition Abstract and Reviews, Series B 62: 787-835.

Ahvenjärvi, S., Vanhatalo, A., Huhtanen, P. \& Varvikko, T. 1997. Rypsirouheen ja lämpökäsitellyn rypsipuristeen vaikutus lypsylehmien pötsistä virtaavien ravintoaineiden mảäräăn. Kotielăintieteen păivăt 1997. Maaseutukeskuksen julkaisuja 914: 191-194.

Aronen, I. \& Vanhatalo, A. 1992. Effect of concentrate supplementation to grass silage diets on rumen fermentation, diet digestion and microbial protein synthesis in growing heifers. Agricultural Science in Finland 1: 177-178.

Aston, K., Fisher, W.J. \& McAllan, A.B. 1994. Intake and production responses by holstein-friesian cows to the level and pattern of crude protein supplied in a fixed concentrate diet given with grass silage ad libitum. BSAS Winter Meeting, Scarborough, UK. Paper 129.

Bosch, M.W., Lammers-Wienhoven, S.C.W., Bangma, G.A., Boer, H. \& Adrichem, P.W.M. van 1992. Influence of stage of maturity of grass silages on digestion processes in dairy cows. 2. Rumen contents, passage rates, distribution of rumen and faecal particles and mastication activity. Livestock Production Science 32: 265-281.

Chamberlain, D.G. 1987. The silage fermentation in relation to the utilization of nutrients in the rumen. Process Biochemistry 22: 60-63.

- \& Choung, J.-J. 1993. The nutritional value of grass silage. In: O'Kiely P. et al. (eds.). Silage Research 1993. Proceedings of the 10 th International Conference on Silage Research. Dublin City University, Ireland, 6-8 September 1993. p. 131-136.

- \& Choung, J.-J. 1995. The importance of rate or ruminal fermentation of energy sources in diets for dairy cows. In: Garnsworthy, P.C. et al. (eds.). Recent Advances in Animal Nutrition. Butterworths, London. p. 3-27.

-, Choung, J.-J. \& Robertson, S. 1992. Protein nutri- tion of dairy cows receiving grass silage diets: effects of feeding a protein supplement of unbalanced amino acid composition. Journal of Food Science and Agriculture 60: 425-430.

- , Martin, P.A. \& Robertson, S. 1989. Optimizing compound feed use in dairy cows with high intakes of silage. In: Haresign, W. \& Cole, D.J.A. (eds.). Recent Advances in Animal Nutrition. Butterworths, London. p. 175-193.

- , Thomas, P.C. \& Anderson, F.J. 1983. Volatile fatty acid proportions and lactic acid metabolism in the rumen of sheep and cattle receiving silage diets. Journal of Agricultural Science, Cambridge 101: 4758.

- , Thomas, P.C., Wilson, W., Newbold, C.J. \& McDonald, J.C. 1985. The effects of carbohydrate supplements on ruminal concentrations of ammonia in animals given diets of grass silage. Journal of Agricultural Science, Cambridge 104: 331-340.

Choung, J.-J. \& Chamberlain, D.G. 1993a. Effects of addition of lactic acid and postruminal supplementation with casein on the nutritive value of grass silage for milk production in dairy cows. Grass and Forage Science 48: 380-386.

- \& Chamberlain, D.G. 1993b. The effects of abomasal infusions of casein or soya-bean-protein isolate on the milk production of dairy cows in mid-lactation. British Journal of Nutrition 60: 103-115.

Clancy, M., Wangsness, P.J. \& Baumgardt, R.B. 1977. Effect of silage extract on voluntary feed intake, rumen fluid constituent, and rumen motility. Journal of Dairy Science 60: 580-590.

Cushanan, A. \& Mayne, C.S. 1995. Effects of ensilage of grass on the performance and nutrient utilization by dairy cattle. 1. Food intake and milk production. Animal Science 60: 337-345.

Danfær, A. 1994. Nutrient metabolism and utilization in the liver. Livestock Production Science 39: 115-127.

Deinum, B., Beyer, J. de, Nordfeldt, P.H., Kornher, A., Østgård, O. \& Bogaert, G. van 1981. Quality of herbage at different latitudes. Netherland Journal in Agri- 
Vol. 7 (1998): 219-250.

cultural Science 29: 141-150.

Demarquilly, C. 1973. Composition chimique, charactéristiques fermentaires, digestibilité et quantité des ensilage de fourrage: modifications par rapport au fourrage initial. Annales de Zootechique 22: 1-35.

Demeyer, D.I. \& Van Nevel, C.J. 1975. Methanogenesis, an integrated part of carbohydrate fermenta tion and its control. In: MacDonald, I.W \& Warner, A.C.I (eds.). Digestion and Metabolism in the Ruminant. University of New England Publishing Unit, Armidale, Australia. p. 366-382.

Ettala, E. \& Lampila, M. 1978. Factors affecting voluntary silage intake by dairy cows. Annales Agriculturae Fenniae 17: 163-174.

- , Lampila, M. \& Rissanen, H. 1978. Effect of concentrate feeding level in grass silage-based diets on milk production of dairy cows. Annales Agriculturae Fenniae 17: 175-185.

Farhan, S.M.A. \& Thomas, P.C. 1978. The effect of partial neutralization of formic acid silages with sodium hydroxide on their voluntary intake by cattle and sheep. Journal of the British Grassland Society 33: 151-158.

Gasa, J., Holtenius, K., Sutton, J.D. \& Dhanoa, M.S. 1991. Rumen fill and digesta kinetics in lactating Friesian cows given two levels of concentrates with two types of grass silage ad lib. British Journal of Nutrition 66: 381-398.

Girdler, C.P., Thomas, P.C. \& Chamberlain, D.G. 1984. Exogenous supply of glucose precursors and nitrogen utilisation in sheep. Proceedings of the Nutrition Society 45: 43A.

Gordon, F.J., Porter, M.G., Mayne, C.S., Unsworth, E.F. \& Kilpatrick, D.J. 1995. Effect of forage digestibility and type of concentrate on nutrient utilization by lactating dairy cattle. Journal of Dairy Reseacrh 62:1527.

- , Unsworth, E.F. \& Peoples, A.C. 1981. Protein supplementation of silage-based diets for milk production. 54th Annual Report, Agricultural Research Institute of Northern Ireland. Belfast, HMSO. p. 13-25.

Harrison, J.H., Blauwiekel, R. \& Stokes, M.R. 1994. Fermentation and utilization of grass silage. Journal of Dairy Science 77: 3209-3235.

Heikkilä, T. 1993. Concentrate supplemented silage or hay harvested at early growth stage in the feeding of dairy cattle. In: Proceedings of the Russia's-Finnish symposium Elaboration of Ecologically Safe Methods for Agriculture", Sanct-Petersburg, Russia, 1993. p. 176-178.

- 1994. Nykyhinnoilla runsas văkirehuannos ei ole taloudellisesti kannattava. Maito ja Me 4/94: 38-40.

-, Toivonen, V. \& Huhtanen, P. 1998a. Effecs of and interactions between the extent of silage fermentation and protein supplementation in lactating dairy cows. Agricultural and Food Science in Finland. (in press).

- , Toivonen, V. \& Huhtanen, P. 1998b. Effect of spring and autumn silage, protein and concentrate level on milk production. Proceedings of the 17th General Meeting of European Grassland Federation. 18-21 May 1998, Debrecen, Hungary. p. 717-721.

- , Văătảinen, H. \& Toivonen, V. 1993. Effects of acid and biological additives on grasss silage quality and milk production in dairy cows supplemeted with concentrates containing three levels of rapeseed meal. In: O'Kiely, P. et al. (eds.). Silage research 1993. Proceedings of the 10th International Conference on Silage Research, Dublin City University, Ireland, 68 September 1993. p. 190-191.

Henning, P.H., Steyen, D.G. \& Meissner, H.H. 1993. Effect of synchronization of energy and nitrogen supply on ruminal characteristics and microbial growth. Journal of Animal Science 73: 142-148.

Huhtanen, P. 1987a. The effects of carbohydrate supplements on the utilization of grass silage diets. Academic dissertation. University of Helsinki.

- 1987b. The effect of dietary inclusion of barley, unmolassed sugar beet pulp and molasses on milk production, digestibility and digesta passage in dairy cows given silage based diet. Journal of Agricultural Science in Finland 59: 101-120.

- 1988. The effects of supplementation of silage diet with barley, unmolassed sugar beet pulp and molasses on organic matter, nitrogen and fibre digestion in the rumen of cattle. Animal Feed Science and Technology 20: 259-278.

- 1992 . The effects of barley vs. barley fibre with or without distiller's solubles on site and extent of nutrient digestion in cattle fed grass silage based diets. Animal Feed Science and Technology 36: 319-337.

- 1993a. The effects of concentrate energy source and protein content on milk production in cows given grass silage ad libitum. Grass and Forage Science 48: 347-355.

- $1993 \mathrm{~b}$. Factors influencing forage intake. In: Fredeen, A. (ed.). Proceedings of Nova Scotia forage conference forage: seeding to feeding. Nova Scotia Forage Council, Canada. p. 103-127.

- Blauwiekel, R. \& Saastamoinen, I. 1998. Effects of intraruminal infusions of propionate and butyrate with two different protein supplements on milk production and blood metabolites in dairy cows receiving grass silage-based diet Journal of Science in Food and Agriculture 77: 213-222.

- \& Heikkilä, T. 1996. Effects of physical treatment of barley and rapeseed meal in dairy cows given grass silage-based diets. Agricultural and Food Science in Finland 5: 399-412.

- \& Hissa, K. 1996. The influence of molasses and yeast culture on the performance of growing bulls on grass silage-based diet. Journal of Animal and Feed Sciences 5: 201-215.

- \& Jaakkola, S. 1994. Influence of grass maturity and diet on ruminal dry matter and neutral detergent fibre digestion kinetics. Archiv for Animal Nutrition 47: 153-167.

- , Jaakkola, S. \& Saarisalo, E. 1995. The effects of concentrate energy source on milk production of dairy cows given a grass silage-based diet. Animal Science 60: 31-40.

- , Miettinen, H. \& Toivonen, V. 1997a. Effects of silage fermentation and postruminal casein supplementation in lactating dairy cows. 1. Diet digestion and milk production. Journal of Science in Food and Agriculture 74: 450-458. 


\section{Seminar in honour of the 100th anniversary of MTT}

- \& Vanhatalo, A. 1997. Ruminal and total plant cell wall digestibility estimated by a combined in situ method utilizing mathematical model. British Journal of Nutrition 78: 583-598.

-, Vanhatalo, A. \& Varvikko, T. 1997b. Effects of abomasal infusions of histidine, leucine and glucose on milk production in cows given grass silage based diet. Journal of Dairy Science 80, Supplement 1: 247.

Jaakkola, S. 1992. Silage fermentation in relation to the feeding value with special reference to enzyme- treated silage. Academic dissertation. University of Helsinki, Finland.

- \& Huhtanen, P. 1992. Rumen fermentation and microbial protein synthesis in cattle given increasing levels of lactic acid with grass silage based diet. Journal of Agricultural Science, Cambridge 119: 411-419.

- \& Huhtanen, P. 1993. The effects of the forage preservation method and the proportion of concentrate on nitrogen digestion and rumen fermentation in cattle. Grass and Forage Science 48: 146-154.

- , Huhtanen, P. \& Hissa, K. 1991. The effect of cell wall degrading enzymes or formic acid on fermentation quality and on digestion of grass silage by cattle. Grass and Forage Science 46: 75-87.

-, Huhtanen, P. \& Kaunisto, V. 1993. VFA proportions and microbial protein synthesis in the rumen of cattle receiving grass silage ensiled with different rates of formic acid. In: O'Kiely, P. et al. (eds.). Silage Research 1993. Proceedings of the 10th International Conference on Silage Research, Dublin City University, Ireland, 6-8 September 1993. p. 139-140.

- , Rinne, M., Heikkilä, T., Toivonen, V. \& Huhtanen, P. 1996. Effects of restriction of silage fermentation with formic acid on milk production. Proceedings of the $X$ Ith International Silage Conference. University of Wales, Aberystwyth 8-11 September 1996. p. 7677.

- Rinne, M., Huuskonen, K., Vesterinen, V. \& Huhtanen, P. 1995. The Effect of silage fermentation on the response to protein supplementation in milk production and rumen fermentation in vitro. VII Symposium on Protein Metabolism and Nutrition, 24-27 May 1995, Estaco Zootecnica Nacional Portugal. p. 235236.

Jacobs, J.L. \& McAllan, A.B. 1992. Protein supplementation of formic acid and enzyme-treated silage. 2. Nitrogen and amino acid digestion. Grass and Forage Science 47:114-120.

Kaustell, K., Mäntysaari, E.M. \& Huhtanen, P. 1998. Concentrate feeding and milk yield based on the field data of milk recorded herds. Agricultural and Food Science in Finland (in press).

Keady, T.W.J. \& Murphy, J.J. 1993. The effects of ensiling on the intake of herbage and milk production by lactating dairy cows. Animal Production 56: 423-424. (abstract).

Khalili, H. \& Huhtanen, P. 1991. Sucrose supplements in cattle given grass silage based diet. 2. Digestion of cell wall carbohydrates. Animal Feed Science and Technology 33: 262-273.

- , Huhtanen, P., Jaakkola, S. \& Varvikko, T. 1995a. The effects or ruminal and duodenal casein infusion on intake of red clocer silage, milk production and microbial protein synthesis. British Society of Animal Science Winter Meeting 1995. Scarborough 20-22 March 1995. Paper No 123. 2 p.

- , Huhtanen, P., Jaakkola, S. \& Varvikko, T. 1995b. The effects of ruminal and duodenal casein infusion on dry matter (DM) intake of red clover silage and rumen pool size, digestion and passage kinetics of neutral detergent fibre (NDF). Annales de Zootechnique 44, Supplement. p. 243.

-, Varvikko, T., Toivonen, V., Hissa, K. \& Suvitie, M. 1997. The effects of added glycerol, or unprotected free fatty acids, or a combiantion of the two on silage intake, milk production, rumen fermentation and diet digestibility in cows given grass silage based diet. Agricultural and Food Science in Finland 6: 349-362.

Lampila, M., Jaakkola, S., Toivonen, V. \& Setälä, J. 1988. Forage conservation and supplementation in cattle rations. Proceedings of the VI World Conference on Animal Production. Helsinki, Finland. p. 51-71.

Madsen, J., Hvelplund, T., Weibjerg, M., Bertilson, J., Olsson, I., Spörndly, R., Harstad, O.m., Volden, H., Tuori, M., Varvikko, T., Huhtanen, P. \& Olafson, B.L. 1995. The AAT/PVT protein evaluation system for ruminants. A revision. Norwegian Journal in Argicultural Science, Supplement 19. 37 p.

Martin, C., Williams, A.G. \& Michalet-Doreau, B. 1994. Isolation and characteristics of the protozoal and bacterial fractions of bovine ruminanl contents. Journal of Animal Science 72: 2962-2968.

Martin, P.A., Chamberlain, D.G., Robertson, S. \& Hirst, D. 1994. Rumen fermentation patterns in sheep receiving silages of different chemical composition supplemented with concentrates rich in starch or digestible fibre. Journal of Agricultural Science, Cambridge 122: $145-150$.

Mertens, D.R. 1994. Regulation of forage intake. In: Fahey, G.C., Jr (ed.). Forage quality, evaluation and utilization. American Society of Agronomy, Madison, WI. p. $450-493$.

Miettinen, H. \& Huhtanen, P. 1996. The effects of ruminal propionate to butyrate ratio on milk production and blood metabolites in dairy cows fed a grass silage based diet. Journal of Dairy Science 79: 851861.

- \& Huhtanen, P. 1997. Effects of silage fermentation and postruminal casein supplementation in lactating dairy cows. 2. Blood metabolites and amino acids. Journal of Science in Food and Agriculture 74: 459468.

Mould, F.L. 1988. Associative effects of feeds. In: Ørskov, E.R. (ed.). World Animal Science B4, Feed Science. Elsevier, Amsterdam. p. 279-292.

Murphy, M., Khalili, H. \& Huhtanen, P. 1993. The substitution of barley by other carbohydrates in grass silage based diets to dairy cows. Animal Feed Science and Technology 41: 279-296.

Nissinen, O. \& Hakkola, H. 1995. Effects of plant species and harvesting system of grassland production in norhern Finland. Agricultural Science in Finland 4: 479-494.

Nsereko, V.L. 1996. Peptidase inhibitors as additives for 


\section{AGRICULTURAL AND FOOD SCIENCE IN FINLAND}

Vol. 7 (1998): 219-250.

silage. Effects on silage characteristics with reference to peptides. PhD Thesis. University of Aberdeen, UK.

Oldham, J.D. 1984. Protein energy relationships in dairy cows. Journal of Dairy Science 67: 1090-1114.

- 1994. Amino acid nutrition of the dairy cow. In: D'Mello, J.P.F. (ed.). Amino Acids in Farm Animal Nutrition. CAB International, UK. p. 351-375.

Pitt, R.H. 1990. Silage and hay preservation. Cornell University Cooperative Extension NRAES-5. p. 53.

Rinne, M., Jaakkola, S., Heikkilä, T., Huhtanen, P. \& Toivonen, V. 1995. Nurmirehun sulavuuden ja văkirehun yhdysvaikutukset lypsylehmillä. Kotielăintieteen päivăt 1995. Maaseutukeskusten Liiton julkaisuja 888: 41-46.

-, Jaakkola, S. \& Huhtanen, P. 1996. Maturity effects of grass ensiled on diet digestion by dairy cows. Proceedings of the 11th International Silage Conference. Aberyswyth, Wales. p. 196-197.

-, Jaakkola, S. \& Huhtanen, P. 1997. Grass maturity effects on cattle fed silage-based diets. 1. Organic matter digestion, rumen fermentation and nitrogen utilization. Animal Feed Science and Technology 67: $1-17$.

Rook, A.J., Gill, M., Willink, R.D. \& Lister, S.J. 1991. Prediction of voluntary intake of grass silages by lactating cows offered concentrates at flat rate. Animal Production 52: 407-420.

Rooke, J.A. \& Armstrong, D.G. 1989. The importance of the form of nitrogen on microbial protein synthesis in the rumen of cattle receiving grass silage and continuous intraruminal infusion of sucrose. British Journal of Nutrition 61: 113-121.

- , Lee, N.H. \& Armstrong, D.G. 1987. The effects of intraruminal infusions of urea, casein and glucose syrup and a mixture of casein and glucose syrup on nitrogen digestion in the rumen of cattle receiving grass silage diets. British Journal of Nutrition 57: 89-98.

Russel, J.B., O'Conner, J.B., Fox, D.G., Van Soest, P.J. \& Sniffen, C.J. 1992. A net carbohydrate and protein system for evaluating diets for cattle. Journal of Animal Science 70: 3551-3561.

Ryhänen, M., Huhtanen, P., Jaakkola, S. \& Ahvenjärvi, S. 1996. EU-jäsenyyden vaikutus maidontuotantoon. In: Ylătalo, M. (ed.). Maatalousyritysten sopeutuminen EU:ssa vallitseviin hintasuhteisiin. University of Helsinki, Department of Ecomics and Management Publications 12: 75-118.

Saarisalo, E., Jaakkola, S. \& Huhtanen, P. 1997. Valkuaistäydennyksen vaikutus maidontuotantokauden loppuvaiheessa. Kotieläintieteen påivăt 1997. Maaseutukeskuksen julkaisuja 914: 167-170.

Storm, E. \& Ørskov, E.R. 1983. The nutritive value of rumen microorganisms in ruminants.1. Large scale isolation and chemical composition of rumen microorganisms. British Journal of Nutrition 50: 463-470.

Strobel, H.J. \& Russel, J.B. 1986. Effect of pH and energy spilling on bacterial protein synthesis by carbohydrate limited cultures of mixed rumen bacteria. Journal of Dairy Science 69: 2941-2947.

Syrjälä, L. 1972. Effect of different sucrose, starch and cellulose supplements on the utilization of grass si- lages by ruminants. Annales Agriculturae Fenniae 11 199-276.

Tesfa, A. 1993. Effects of rape-seed oil supplementation on digestion, microbial protein synthesis and duodenal microbial amino acid composition in ruminants. Animal Feed Science and Technoiogy 41: 313-328.

Thomas, C. \& Rae, R.C. 1988. Concentrate supplementation of silage for dairy cows. In: Garnsworthy, P.C. (ed.). Nutrition and Lactation in the Dairy Cow. Butterworths, London. p. 327-354.

- \& Thomas, P.C. 1985. Factors affecting the nutritive value of grass silage. In: Cole, D.J.A. (ed.). Recent Advances of Animal Nutrition. Butterworths, London. p. 223-256.

Thomas, P.C., Chalmers, J.C., Chamberlain, D.G. \& Belibasakis, N. 1980. The effect of diet on the content and compostion of crude protein in milk. In: Oslage, H.J. \& Rohr, K. (eds.). Proceedings of 3rd European Association Symposium on Protein Metabolism and Nutrition. Braunschweigh, Germany. Vol II: 522-528.

- \& Chamberlain, D.G. 1982. Silage as a foodstuff. In: Rook, J.A.F. \& Thomas, P.C. (eds.). Silage for Milk Production. Technical Bulletin. National Institute for Research in Dairying, Reading, England. p. 63-101.

Tuori, M. 1992. Rapeseed meal as a supplementary protein for dairy cows on grass silage-based diet, with the emphasis on the Nordic AAT-PBV feed protein evaluation system. Agricultural Science in Finland 1: 367-439.

- , Kaustell, K. \& Huhtanen, P. 1998. Comparison of the protein evaluation systems of feed for dairy cows. Livestock Production Science (in press)

- , Kaustell, K., Syrjälä-Qvist, L. \& Kajaste, S. 1992. Digestibility of silage from meadow fescue and tall fescue grass harvested at different growth stages. In: Proceedings of the 14th General Meeting of European Grassland Federation. Lahti, Finland. p. 252-255.

- , Kaustell, K., Valaja, J., Aimonen, E, Saarisalo, E. \& Huhtanen, P. 1996. Rehutaulukot ja ruokintasuositukset. (Feed tables and feeding recommendatios). Helsinki. 99 p.

- , Syrjălä-Qvist, L. \& Kokkonen, T. 1993. Rumen fermentation and passage rate of digesta of direct cut and prewilted grass silage. In: O'Kiely, P. et al. (eds.). Silage Research 1993. Proceedings of the 10th International Conference on Silage Research, Dublin City University, Ireland. p. 143-144.

Vanhatalo, A. 1995. Assessment of intestinal feed nitrogen digestibility in ruminants by mobile-bag method. Academic dissertation. University of Helsinki, Finland. 44 p. +5 app.

- , Heikkilă, T. \& Găddnăs, T. 1995a. Puna-apilapitoinen săilörehu lypsylehmien ruokinnassa: vaikutus valkuaissynteesiin, pötsifermentaatioon ja maidon tuotantoon heinäsäilörehuun verrattuna. Kotieläintieteen päivåt 1995. Maaseutukeskusten Liiton julkaisuja 88: 190-193.

- , Heikkilä, T. \& Gäddnăs, T. 1995b. Microbial protein synthesis in dairy cows fed grass silage or red clover-grass silage. In: VII Symposium on Protein Metabolism and Nutrition: Abstracts, 24-27 May 1995, Estacao Zootecnica Nacional, Portugal. p. 88. 


\title{
AGRICULTURAL AND FOOD SCIENCE IN FINLAND
}

Seminar in honour of the 100th anniversary of MTT

- , Huhtanen, P. \& Varvikko, T. 1997. Response of dairy cows fed grass silage based diets to the abomasal infusions of histidine alone or in combinations with methionine and lysine. Journal of Dairy Science 80, Supplement 1: 257.

- \& Toivonen, V. 1993. Microbial protein synthesis in cattle fed silage cut fro grass fertilized with different level of N. In: O'Kiely, P. et al. (eds.). Silage Research 1993. Proceedings of the 10th International Conference on Silage Research, Dublin City University, Ireland, 6-8 September 1993. p. 168-169.

- , Varvikko, T. \& Aronen, I. 1992. The effect of type of additive on rumen fermentation and digestion of grass silage in cattle. Agricultural Science in Finland 1: 163175.

Van Soest, P.J., Mertens, D.R. \& Deinum, B. 1978. Preharvest factors influencing quality of conserved forage. Journal of Animal Science 47: 712-720.

van Vuuren, A.M., Huhtanen, P. \& Dulphy, J.-P. 1995. Improving the feeding and health value of ensiled forages. In: Journet, M. et al. (eds.). Recent Developments in the Nutrition of Herbivores. INRA, Paris.

\section{p. $297-307$.}

Varvikko, T. 1986. Evaluation of rumen-undegraded feed protein. Academic dissertation. University of Helsinki, Finland.

- , Vanhatalo, A. \& Huhtanen, P. 1997. Lactational and metabolic responses to abomasal methionine and lysine infusions in dairy cows fed grass silage based diet. Journal of Dairy Science 80, Supplement 1: 249.

Vérité, R., Faverdin, P. \& Agabriel, J. 1997. Developments in the INRA feeding systems for dairy cows. In: Garnsworthy, P.C. \& Wiseman, J. (eds.). Recent Advances of Animal Nutrition 1997. Butterworths, London. p. 153-166.

Webster, A.J.F. 1992. The metabolisable protein system for ruminants. In: Garnsworthy, P.C. et al. (eds.). Recent Advances of Animal Nutrition 1992. Butterworths, London. p. 93-110.

Wilkins, R.J., Hutchinson, K.J., Wilson, R.F. \& Harris, C.E. 1971. The voluntary intake of silage by sheep. 1. Interrelationships between silage composition and intake. Journal of Agricultural Science, Cambridge 77: 531-537.

\section{SELOSTUS}

\section{Ravintoaineiden saantiin ja maidontuotantoon vaikuttavat tekijät runsaalla säilörehuruokinnalla}

\author{
Pekka Huhtanen \\ Maatalouden tutkimuskeskus
}

Tämän kirjallisuuskatsauksen tavoitteena on selvittää ravintoaineiden saantiin ja maidontuotantoon vaikuttavia tekijöitä ruokinnan perustuessa runsaaseen säilörehun käyttöön. Suomessa rajoittuneesti käynyt säilörehu on maidontuotannon perusta. Nurmisäilörehun viljaa suurempi satopotentiaali ja pienemmät sääriskit, lyhyt laidunkausi sekä pohjoisilla leveysasteilla kasvaneen nurmirehun hyvä sulavuus ovat edistäneet säilörehuun perustuvan ruokintasysteemin kehittämistä.

Nurmen korjuuhetken kehitysaste on tärkein rehuannoksen sulavuuteen vaikuttava tekijä. Sen sijaan väkirehun määrä ja valkuaispitoisuus vaikuttavat sulavuuteen yleensä vähän. Säilörehun syöntiin vaikuttavat sekä rehun sulavuus että käymislaatu. Rajoittuneesti käynyt säilörehu tuottaa pötsissä runsaasti mikrobivalkuaista, mutta niukka propionihapon tuotanto pötsissä voi rajoittaa mikrobivalkuaisen hyväk- sikäyttöä maitovalkuaisen tuotannossa. Väkirehun määrän lisäyksellä saadut tuotosvasteet ovat melko pieniä etenkin, kun väkirehun päivittäinen käyttömäärä ylittää 10 kg. Korkea säilörehun syönnin korvaussuhde, rehun sulatuksen negatiiviset yhdysvaikutukset ja energian siirtyminen kudosvarastoihin selittävät lisäväkirehun huonoa tuotosvastetta. Rypsirehuina annettu valkuaistäydennys on poikkeuksetta lisännyt maitovalkuaisen tuotantoa, mutta lehmien tuotostaso, säilörehun valkuaispitoisuus, väkirehun määrä tai lypsykauden vaihe ei näytä vaikuttavan tuotosvasteiden suuruuteen. Uusi valkuaisjärjestelmä ennustaa tuotosvasteet tavallisimmilla dieeteillä erittäin hyvin. Sen sijaan lisävalkuaisen korkea hyväksikäyttö (noin 0,50 ) viittaa siihen, että valkuaisen hyväksikäyttö on erittäin tehokasta ja nykyiset valkuaisen ruokintasuositukset ovat todennäköisesti liian pienet. 